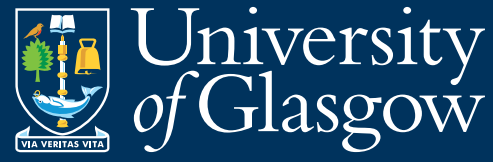

Adam Smith

Business School

WORKING

PAPER

SERIES

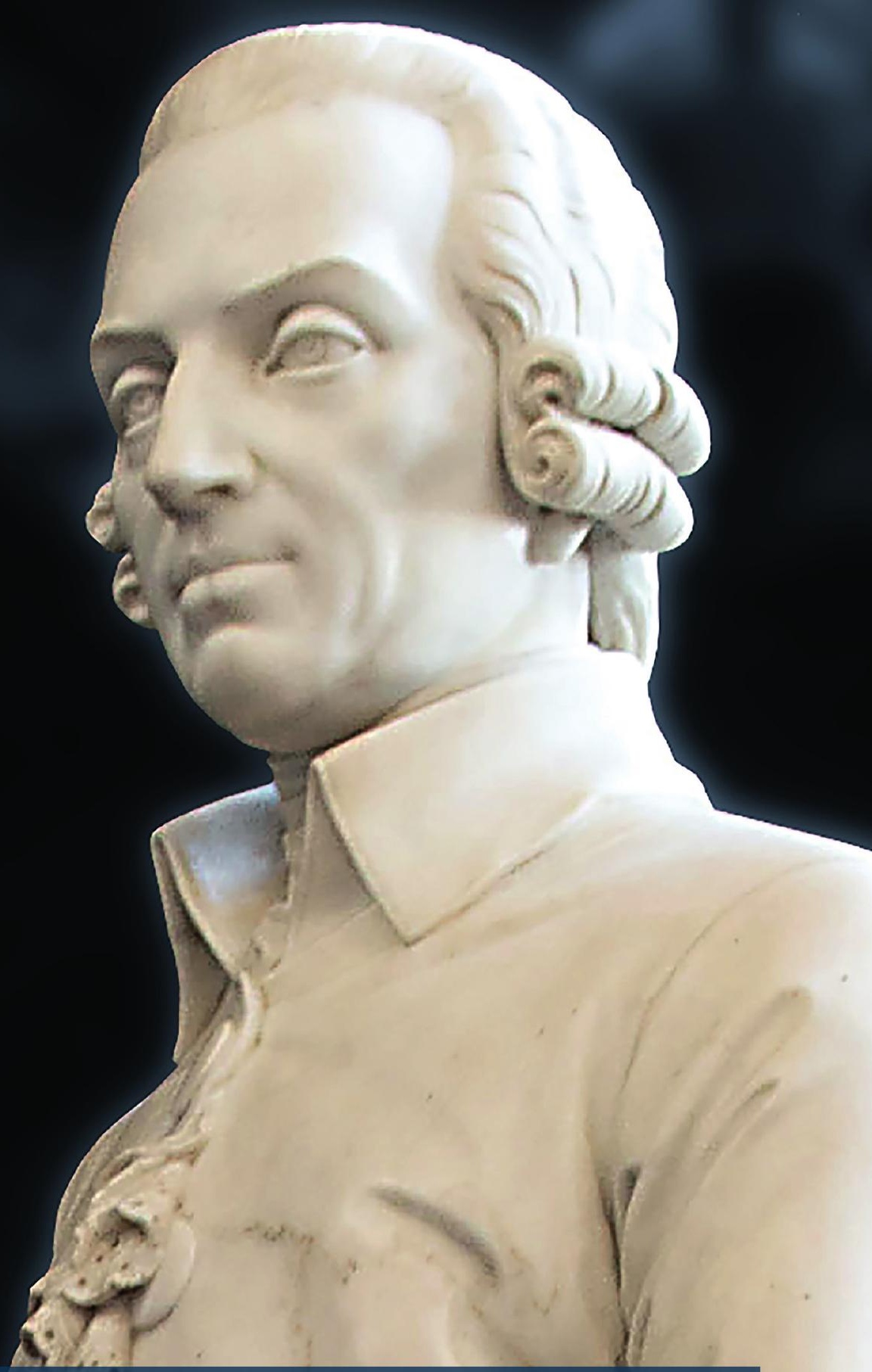

Gender board diversity and the cost of bank loans

Panagiotis Karavitis, Sotirios Kokas and Serafeim Tsoukas

Paper no. 2020-25

September 2020 


\title{
Gender board diversity and the cost of bank loans *
}

\author{
Panagiotis Karavitis $^{\dagger} \quad$ Sotirios Kokas ${ }^{\ddagger} \quad$ Serafeim Tsoukas ${ }^{\S}$
}

September 2020

\begin{abstract}
We examine the relationship between female board representation and the cost of lending, using a dataset of 13,714 loans from 386 banks matched with 2,432 non-financial firms from 1999 to 2013. We find that firms with female directors command lower loan spreads. In addition, female independent directors have a stronger impact on lowering spreads compared to female directors' other attributes. However, as firms build relationships with their lenders this effect becomes less potent. Finally, when we introduce firm-level heterogeneity we document that changes in gender diversity exert a stronger impact on the cost of lending in the case of bank-dependent firms, especially for relationship borrowers.
\end{abstract}

Key words: Gender diversity; Board of directors; Bank loans; Relationship lending JEL: G21, G30

${ }^{*}$ We are grateful to Douglas Cumming and Geoffrey Wood (editors) and three anonymous reviewers for insightful comments and suggestions. We also acknowledge Pavlos Dimitratos, Nuri Ersahin, Franco Fiordelisi, Jens Hagendorff, Martin Jacob, Pantelis Kazakis, William Megginson, Alex Michaelides, Stefan Ruenzi, Stylianos Zyglidopoulos, and participants at the 2019 EFiC Conference in Banking and Corporate Finance and the 2020 British Academy of Management in the Cloud for their useful comments.

${ }^{\dagger}$ Corresponding author: Adam Smith Business School, University of Glasgow, University Avenue, G12 8QQ, UK. E-mail: Panagiotis.Karavitis@glasgow.ac.uk

${ }_{\ddagger}^{\ddagger}$ Essex Business School, University of Essex, Wivenhoe Park, Colchester CO4 3SQ, UK. E-mail: skokas@ essex.ac.uk.

$\S$ Adam Smith Business School, University of Glasgow, University Avenue, G12 8QQ, UK. E-mail: Serafeim.Tsoukas@glasgow.ac.uk 


\section{Introduction}

The extant literature on corporate governance uses a combination of legislation and agency costs alleviation to explain why, in various settings, boards are central in governing organizations (Hermalin and Weisbach (2003)). Importantly, the structure of the board is a critical factor in influencing the integrity of the financial accounting process through auditing and disciplining senior management (Anderson, Mansi and Reeb (2004)). In turn, recent turmoil in the financial markets has focused attention on corporate social responsibility (CSR), particularly on the role and the composition of corporate boards of directors (Terjesen, Sealy and Singh (2009)). ${ }^{1}$ For instance, one way improved CSR performance can generate value in the long run is by relaxing credit constraints that firms face on the supply side, from financial markets and financial intermediaries (Cheng, Ioannou and Serafeim (2014)). Hence, superior CSR levels are more likely to ease access to external financing, which may then also improve financial costs.

Why would improving board diversity, especially gender diversity, matter for the cost of external financing? Female presence is key to enhancing corporate financial performance and reputation (Bear, Rahman and Post (2010)). In addition, board diversity could improve the quality of board discussions and increase the ability of a board to provide greater transparency (Carter, Simkins and Simpson (2003). Adams and Ferreira (2009) note that female representation provides greater oversight of managers' actions and accounting reports through promoting better board attendance, more auditing, and demanding greater accountability from managers. Finally, female directors tend to be more concerned with reducing negative business practises (Cumming, Leung and Rui (2015)). Therefore, previous research on women on corporate boards examines the characteristics of female directors and their favourable traits that may enhance board decision-making, tasks, and roles, paying attention to firm performance (Tanaka (2014)).

\footnotetext{
${ }^{1} \mathrm{CSR}$ is difficult to conceptualize and remains open to different interpretations (Wood (2010)). A widely adopted interpretation is that CSR is made of demonstrable actions and outcomes reflecting business responsibility for societal good (Galbreath and Shum (2012)).
} 
In this paper, we argue that the cost of obtaining bank loans hinges, at least to some extent, on the board of directors and female presence more specifically. We follow the line of inquiry in Anderson, Mansi and Reeb (2004), which shows that female board representation is related to improved accounting processes. This is achieved through transparent financial reporting that complements screening and monitoring, which ultimately implies a reduction in agency costs. Therefore, our hypothetical argument is: When female board representation increases, accounting practices improve and loan interest rates decrease. Hence, banks observe this favourable trait of gender diverse boards and provide those firms with lower-interest loans.

The motivation to focus on bank financing stems from two important considerations. First, board attributes influence the validity of accounting statements by increasing the disclosure of firm-specific information and improving incentives for collecting private information (Gul, Srinidhi and Ng (2011)). This is of great importance for the lending process because accounting-based information is the traditional standard that potential lenders use to assess a firm's credit quality using public information. Second, bank loans provide a major source of financing, even for large public companies significantly affecting firms' financial structure (Bradley and Roberts (2015)). Finally, we examine the extent to which this link differs at firms that have established relationships with their lenders compared to their counterparts, as well as to firms that are more and less bank dependent.

To implement our empirical analysis we use data from four different data sources: Thomson Reuters LPCs DealScan database, Call Reports from the Federal Reserve Board of Governors (FRB), Compustat, and BoardEx over the period 1999 to 2013. Our dataset has two appealing characteristics to study the above questions. First, it disentangles internal and independent directors and enables us to delve deeper into the role of different female directors' attributes. Second, the matching between firms and their corresponding lenders allows us to evaluate the impact of gender diversity taking into account relationship lending.

The empirical challenge to estimate the impact of gender-diverse boards on the cost of 
borrowing lies in dealing with the endogeneity between the various measures of "firm-specific performance" and firms' choices about corporate governance (e.g., see Hermalin and Weisbach (1998), Minnick and Noga (2010), among others). Our research design enables us to mitigate significantly these endogeneity concerns. First, to identify the impact of female directors on the cost of lending, we control not only for firm-specific (e.g., see Anderson, Mansi and Reeb (2004)) but also for bank-specific attributes. Second, the multi level structure of our sample stemming from multiple loans provided by the same bank to different firms allows us to include comprehensive sets of time-invariant and time-varying fixed effects to saturate our empirical identification from omitted factors.

We perform a number of additional tests to corroborate our results. Notably, we focus on a two-stage instrumental variable (IV) analysis that circumvents endogeneity concerns by exploiting the role of directors' retirements. In doing so, we establish the appropriateness of Retired director as an exclusion restriction for female participation, and then, we utilize it to mitigate concerns about simultaneity bias. In addition, we control for the firms' credit ratings at the time of the loan origination to deal with a major factor that may affect loan pricing. The credit rating reflects the probability of default, and thus we alleviate creditquality differences on top of the gender diversity, such as expected losses.

In the first set of estimates, we find evidence that gender diversity on boards has a negative and significant effect on firms' cost of lending. More precisely, increasing the fraction of females on the board by $1 \%$ reduces, on average, the loan spread by 20.8 basis points. However, the effect diminishes by 4.2 basis points for repeated borrowing from the same lender because the quality of the financial reporting has already been discounted from the bank in the first interaction. Moreover, the effect is more potent for highly bank-dependent firms. Thus, we conclude that gender diversity improves reporting quality and reduces loan costs. However, bank acquisition of private information from relationship lending reduces the verification cost and the discount rate. These results unify the mixed evidence on the board's gender diversity, providing new insights from a bank's perspective. Our findings are 
robust to non-pricing characteristics and respecification models.

We contribute to the literature in three main ways. First, we examine the extent to which female board representation reduces information asymmetry between lenders and borrowers with implications for the cost of bank lending. Previous empirical studies find that female CFOs reduce the cost of bank loans (Francis, Hasan and Wu (2013)), while Pandey, Biswas, Ali and Mansi (2019) and Usman, Farooq, Zhang, Makki and Khan (2019) conclude that female presence on the board is negatively associated with the cost of debt, as proxied by interest expense over debt. The latter approach relies on approximating the cost of debt and, due to the aggregation, it can be influenced both by increases in expenses (numerator) and reduction in debt (denominator). Our approach using granular data allows us not only to remove demand-side influences, but also to examine the channel through which women directors influence firms' cost of bank borrowing. When we distinguish between female executives and female independent directors, we observe that the effect is stronger for the latter. Hence, our results suggest female independent directors affect the cost of borrowing.

Second, we account for the role of relationship lending in examining how gender diversity affects the cost of bank lending. Building relationships is a major way for banks to find out more about their borrowers, cherry-pick good projects, and consequently be associated with a lower degree of adverse selection (Boot (2000)). We add to the literature on gender diversity and firm performance by recognizing that gender diversity may affect firms' cost of lending, especially as they establish relationships (or track records) with banks through repeated interactions. Exploiting the link between gender diversity and the cost of bank loans, through the relationship-lending lens, provides an alternative explanation of the direct link between board gender diversity and the cost of borrowing. In other words, we highlight the lending relationships as a mechanism to mediate the direct impact. To this end, relationship lending presents a unified framework that nests the full spectrum of corporate governance.

Finally, although this study relates to the burgeoning literature on firm heterogeneity and real activities (Whited and $\mathrm{Wu}$ (2006) and Campello and Chen (2010)), we focus on 
the interplay between board diversity and bank dependency. It is now well documented that during the most recent global financial crisis, banks incurred severe losses, which led them to significantly increase the cost of loans to bank-dependent firms (Santos (2011)). Also considering that not all firms' lending costs respond to changes in the board composition in the same way, we set out to examine the loan-pricing implications of firms' bank dependency.

The rest of the paper is structured as follows. Section 2 presents an overview of the related literature and develops our testable hypotheses. Sections 3 and 4 contain our methodology and data-set description, respectively. Section 5 presents the empirical results, while section 6 explains the robustness checks undertaken. Section 6 provides conclusions and policy implications.

\section{Conceptual framework and hypotheses}

\subsection{The link between gender diversity and the cost of bank loans}

The broad thrust of the empirical evidence supports the argument that board characteristics affect firm performance either in a direct or in an indirect way through the board's actions (Hermalin and Weisbach (2003)). ${ }^{2}$ To begin with the mix of men and women on the board, the direct link is achieved primarily via a reduction of agency costs. Specifically, Gul, Srinidhi and $\mathrm{Ng}$ (2011) show that gender-diverse boards make firms more transparent by increasing the disclosure of firm-specific information by managers and by providing incentives for the collection of private information by investors. In addition, gender board diversity can improve the quality of board discussions, ensure that more information circulates from the board to investors, increase efforts being put into oversight and monitoring (Hillman, Shropshire and Cannella (2007), Adams and Ferreira (2009)), promote better board attendance, and lead to greater accountability for poor performance. Women can be more vocal than their male

\footnotetext{
${ }^{2}$ However, the empirical evidence of a direct link between gender diversity and financial performance remains mixed and inconclusive. See Terjesen, Sealy and Singh (2009) for a detailed review of the role of gender diversity in firms' performance.
} 
counterparts (Carter, Simkins and Simpson (2003), Adams and Ferreira (2009)) and Ray (2005) argues that compared with men, women possess many favourable traits in value judgment, risk attitude, and decision-making. In sum, several studies document a positive relationship between gender diversity on the board and corporate performance (see, for example, Gul, Srinidhi and Ng (2011), Liu, Wei and Xie (2014), Chen, Leung and Goergen (2016)).

On the other hand, other researchers conclude that gender diversity in the boardroom does not necessarily improve firm outcomes (Gilbert and Ivancevich (2000), Mannix and Neale (2005), Adams and Ferreira (2009), Boone and Hendriks (2009), Sila, Gonzalez and Hagendorff (2016)). ${ }^{3}$ In addition, Ahern and Dittmar (2012) and Matsa and Miller (2013) find that firm value decreases following the introduction of the $40 \%$ gender quota for directors in Norway. ${ }^{4}$ Motivated by the inconsistent findings for a direct link between female directors and financial performance, Galbreath (2018) shows that female directors can enhance firms' financial performance by influencing corporate social responsibility. This finding paves the way for identifying an indirect link between gender diversity and firms' financial performance.

In the present study, we follow literature's insights on gender diversity on boards and firm performance. In doing so, we argue that female board representation can improve transparency by increasing managerial auditing and enhancing financial accounting processes. ${ }^{5}$ Thus, female representation reduces adverse selection, stemming from the firm having private information that banks do not have, which complements the screening and monitoring

\footnotetext{
${ }^{3}$ Scholars posit that the ability to increase the amount of information available to investors can have a positive effect on firm risk. For instance, several studies find that gender-diverse boards reduce firm risk, because men are more likely to engage in risky decisions compared to their female counterparts (Hinz, McCarthy and Turner (1997), Byrnes, Miller and Schafer (1999), Barber and Odean (2001)). Adams and Ferreira (2004) also find that firms facing more variability in their stock returns have fewer women on their boards.

${ }^{4} \mathrm{~B} \varnothing \mathrm{hren}$ and Staubo (2014) further show that the mandatory gender balance in Norway may produce firms with inefficient boards.

${ }^{5}$ The boards of directors delegate direct oversight of the financial accounting process to the audit committee, which is a subcommittee of the full board. Audit committees are responsible for recommending the selection of external auditors to the full board (supervisory or non-executives), ensuring the soundness and quality of internal accounting and control practices, and monitoring external auditor independence from senior management. Boards meet routinely with the firm's accounting staff and external auditors to review financial statements, audit procedures, and internal control mechanisms (Klein (2002)).
} 
role of banks and thus reduces the cost of borrowing. ${ }^{6}$ This is supported by Francis, Hasan and $\mathrm{Wu}$ (2013), who show that female CFOs borrow with better terms from the banks. In addition, L.Paige-Fields, Fraser and Subrahmanyam (2012) find that firms' board quality and other governance characteristics influence the likelihood that lenders will provide debt covenants and lower-cost bank loans. ${ }^{7}$ Finally, Pandey, Biswas, Ali and Mansi (2019) and Usman, Farooq, Zhang, Makki and Khan (2019) conclude that female directors are negatively related to the cost of debt, which is proxied by interest expenses over debt. In the present study, our main interest lies in understanding how banks perceive diversity on boards when it comes to the cost of lending. In light of the above discussion, we formulate the first hypothesis as follows.

Hypothesis 1a: Firms with more gender-diverse boards are likely to command lower loan spreads.

\subsection{The mediating role of relationship lending}

Having a gender-diverse board likely has a direct effect on the cost of borrowing, but there might be alternative explanations. Specifically, an alternative explanation is that female directors may influence loan spreads indirectly through bank relationships. Bank-firm relationship lending facilitates screening and monitoring because the bank accumulates inter temporal firm-specific information from repeated interactions with the firm, which adds value (Diamond (1984), Allen (1990), Winton (1995)). Relationship lending is a key mechanism to mitigate moral-hazard and adverse-selection problems in loan contracting (Boot (2000)). However, banks' acquisition of private information could effectively "lock-in" firms and make it possible to extract higher rents (Greenbaum, Kanatas and Venezia (1989)). Relationship

\footnotetext{
${ }^{6}$ In the era of financial technology, banks rely heavily on artificial intelligence and machine-learning methods to measure credit banking risk. The usage of high technology is more potent in the syndicated loan market, where aggregated bank' exposure is, on average, larger than in conventional corporate loans (PrezMartn, Prez-Torregrosa and Vaca (2018)). Thus, the structure of the board becomes of grave importance for banks that become adversely exposed to new financial products and price the risks accordingly.

${ }^{7}$ The authors include the percentage of female directors among their board characteristics but find no significant effect.
} 
lenders exploit their privileged information and exert monopolistic rates to compensate for the costly access to and processing of proprietary information that is unavailable to outside lenders.

As mentioned, female board diversity increases the transparency and reliability of firms, reducing adverse selection and consequently the cost of borrowing. We argue that once banks create relationship lending, the effect of female board diversity decreases in relationship loans, possibly due to an informational "lock-in." In other words, the impact of female diversity is likely short-lived as firms establish relationships with banks through repeated loans. Gender board diversity may reduce firm risk, and consequently, the cost of borrowing, the first time a firm borrows from a bank. However, this effect diminishes once firms establish bank relationships. Following this discussion, we formulate our next hypothesis.

Hypothesis 1b: The negative association between gender-diverse boards and loan spreads is less powerful for relationship borrowers.

\subsection{The amplifying role of bank dependency}

An implication of the mechanism described in the previous subsection is that when lending relationships evolve, for particular firms, the decrease in the cost of borrowing and financing economic activities attenuates. The "lock-in" effect is likely more prevalent for borrowers with few or no alternative sources of external financing beyond the relationship bank (Bharath, Dahiya, Saunders and Srinivasan (2009)). Therefore, we focus on bank-dependent firms. According to Kashyap, Stein and Wilcox (1993), bank-dependent firms are associated with higher degrees of information asymmetry. That is, bank-dependent firms face higher agency costs of borrowing (a higher "external premium") for raising capital from financial markets compared with the cost of internal financing from retained earnings as explained by subsequent effects on real activity (Bernanke and Gertler (1995)). In the context of the loan market, the cost of obtaining loans for financially constrained firms should be particularly sensitive to female board representation when firms become relationship borrowers. 
Following Santos and Winton (2008) we classify firms as bank dependent if they have not had access to the public debt markets (bond or equity issuance) within a five-year window prior to the current loan issuance.

Our study is motivated by this literature and seeks to examine why financially weak firms, which are associated with a higher informational asymmetry, experience higher loan spreads when they become relationship firms. We postulate that financially constrained firms' business fundamentals are systematically more sensitive to aggregate economic movements than unconstrained firms' fundamentals (Kashyap, Stein and Wilcox (1993), Bernanke and Gertler (1995), Campello and Chen (2010) and Whited and Wu (2006)). Consequently, we anticipate that the effect of gender diversity is stronger for firms exhibiting financial constraints compared to their less constrained counterparts. In summary, we expect to find that bank-dependent firms' loans command higher ex-ante excess risk premia when they are "locked-in" lending relationships. Our next hypothesis is as follows.

Hypothesis 2: The effect of board diversity is stronger for firms classified as bank dependent when they become relationship borrowers.

\section{Empirical implementation}

\subsection{Baseline model}

To examine how gender diversity affects bank loan spreads, we estimate the following model:

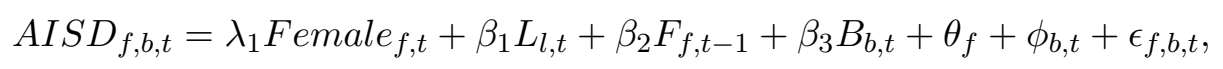

where $A I S D_{f, b, t}$ (abbreviated from All-In-Drawn-Spread) is the coupon spread over Libor on the drawn amount plus the facility fee (in basis points) of loans from bank $b$ to firm $f$ in year t. Female measures female participation on a board. Many studies in corporate governance literature measure board gender diversity as a proportion of females (see for example, Adams and Ferreira (2009), Ahern and Dittmar (2012), Liu, Wei and Xie (2014) and Sila, Gonzalez 
and Hagendorff (2016)). Other studies rely on the number of women directors on a board (Simpson, Carter and D'Souza (2010) and Liu, Wei and Xie (2014)). This approach stems from the idea that female directors need to reach a threshold (otherwise known as a critical mass) before others feel their influence. ${ }^{8}$ Following recent corporate governance literature (see for example Liu, Wei and Xie (2014), Gul, Srinidhi and Ng (2011), among others) we utilise both measures. More precisely, we employ the fraction of females on a board for our baseline analysis and the absolute number as an alternative measure of gender diversity. $\theta_{f}$, and $\phi_{b, t}$ denote different levels of time-invariant and time-varying fixed effects (analyzed later), while $\epsilon$ is a loan-level shock, that captures stochastic disturbances. The coefficient of interest, $\lambda_{1}$, reflects the change in the cost of lending for firms with gender-diversified boards. If diversified firms have lower spreads compared to less diversified firms, then $\lambda_{1}<0$. This finding would support H1a.

Consistent with previous studies (e.g., Sufi (2007), Ivashina and Scharfstein (2010)), we include several loan-level $(L)$ and bank-level $(B)$ control variables to rule out other possible explanations for our results (for more extensive definitions, see table 1). Loan facilities mainly differ in maturity, loan scale, purpose, and loan type (term loan vs. revolver). Thus, we control for these differences by adding loan-level variables that include a dummy that equals 1 when a bank and firm have had a relationship in the previous five years (Bharath, Dahiya, Saunders and Srinivasan (2009)); a dummy that equals 1 if the loan has financial covenants to control for unobservable borrower risk factors (Carey and Nini (2007)); the loan duration in months; and a dummy that equals 1 if the loan is a term. Concerning the bank-level control variables, we use the natural logarithm of total assets (Bank size) and a dummy equal to 1 if the lead arranger is one of the top three arrangers (Bank of America, Citigroup, or JPMorgan Chase) in the syndicated loan market.

In vector $F$ we use a number of firm-level variables that influence loan spreads. First, we use Firm size, measured as the natural logarithm of total assets, to control for the fact that

\footnotetext{
${ }^{8}$ The actual number of females on a board may be important for the composition of the various committees and the allocation of members (see for example Anderson, Mansi and Reeb (2004)).
} 
larger firms have better access to external financing as they are less financially constrained, while smaller firms are more dependent on short-term bank financing (Bougheas, Mizen and Yalcin (2006), Almeida and Campello (2010)). Second, we construct a measure of profitability that proxies for a firm's ability to generate profits relative to total assets. ${ }^{9}$ Third, we calculate Tobin's $Q$ using the market value of a firm's equity divided by the book value of equity. The literature postulates that firms with greater expansion opportunities are less likely to issue bonds earlier (Hale and Santos (2008)). Finally, we take into account the firm's participation in the New York Stock Exchange ( $N Y S E)$ by generating a dummy variable for whether a firm is listed. We argue that quoted firms are likely to command lower loan spreads as they have alternative sources of external financing and can signal credit quality through previous market participation. The timing of the variables is in line with the idea that firms with certain characteristics at time $t$-1 seek loans at time $t$ from a bank (or several banks). In addition, banks at time $t$ will check firms' available financial statements from the previous period $(t-1)$ to decide whether to make the loan.

The key identification challenge is to isolate changes from loan supply and demand. Firms with higher gender diversity that borrow from banks are on average bigger, so the cost of lending is likely correlated with diversified firms. Due to the granularity of our data (loanlevel), we can overcome this issue using several fixed effects. First, bank and industry (at 3 digit SIC) fixed effects are particularly important because we control for time-invariant bankand-industry characteristics that could lead to correlation between $\lambda_{1}$ and $\epsilon$. The inclusion of year and purpose fixed effects accounts for annual common shocks and insulates our model from differences in syndicate structure due to purpose (Sufi (2007)).

Also, bank* year fixed effects $\left(\phi_{b, t}\right)$ allow gender diversity to affect each bank at each point in time heterogeneously. We thus control for unobservable time-varying bank fundamentals (such as profitability, risk, and other balance sheet characteristics) to isolate credit supply. Essentially, we are comparing the same bank lending to different firms in a given year,

\footnotetext{
${ }^{9}$ More profitable firms have a greater cushion for servicing debt and would be expected to pay lower spreads on their loans (see Güntay and Hackbarth (2010)).
} 
while using only the within variation of each bank-firm combination for estimation (Jiménez, Ongena, Peydró and Saurina (2014)). After absorbing any changes in loan supply, our estimates reflect loan demand effects.

\subsection{Relationship lending}

As argued in subsection 2.2, our focus is on the differential effect of relationship lending on loan spreads for firms with gender-diverse boards. Formally we test the following model:

$$
\begin{aligned}
\text { AISD }_{f b t}=\lambda_{1} \text { Female }_{f, t}+\lambda_{2} R E L_{f, b, t}+\lambda_{3}{\text { Female } * R E L_{f, b, t}}+\beta_{1} L_{l, t} & +\beta_{2} F_{f, t-1}+\beta_{3} B_{b, t} \\
& +\theta_{f}+\phi_{b, t}+\epsilon_{f, b, t}
\end{aligned}
$$

where $R E L$ is a measure of relationship strength that equals 1 if a bank lends to the same borrower in the last five years before the present loan, and zero otherwise (Bharath, Dahiya, Saunders and Srinivasan (2009)). ${ }^{10}$ To support H1b, we should observe negative coefficients for both $\lambda_{1}$ and $\lambda_{2}$ and a positive coefficient on the double-interaction term $\lambda_{3}$. This would imply that loan spreads and gender diversity are negatively related, but less so for relationship borrowers.

\subsection{Bank dependency}

Finally, we take into account how bank dependency affects the relationship between the cost of lending and gender diversity. Following Santos and Winton (2008) we generate a dummy variable for bank-dependent firms that equals 1 if they have not had access to the public debt markets (bond or equity issuance) within a five-year time window prior to the current loan issuance. The intuition is this group of firms is more likely to face binding financing constraints and is associated with higher levels of information asymmetry. Thus, they are likely to suffer more from capital market imperfections than their less bank-

\footnotetext{
${ }^{10}$ Also, in section 6.3 we calculate continuous measures of relationship lending.
} 
dependent counterparts. With reference to the "lock-in" effect, the greater the information opacity, the greater the borrower lock-in effect (Bharath, Dahiya, Saunders and Srinivasan $(2009))$.

Therefore, we estimate equation (3.2) for two sub-samples (bank-dependent and nondependent firms). These specifications capture how firm-level heterogeneity, measured by firms' reliance on bank financing, affects the way loan spreads respond to gender diversity in firms more and less likely to suffer from financial constraints. To support H2 we would expect changes in gender diversity to exert a stronger impact on the cost of lending for bank-dependent firms, especially for relationship borrowers.

\section{Data and summary statistics}

\subsection{Data description}

We construct a unique dataset using information from four different data sources. Our data sources are the Thomson Reuters LPCs DealScan database, the Call Reports from the Federal Reserve Board of Governors (FRB), Compustat, and BoardEx. We combine them to cast light on how gender diversity affects the cost of borrowing in the United States. The data covers loan frequency from 1999 to 2013.

We begin with a brief description of the syndicated loan market, as it is extensively analyzed (e.g., Sufi (2007); Delis, Kokas and Ongena (2017) for further details). Syndicated loans are granted by a group of banks to a single borrower. Loan syndication allows banks to compete with capital markets for relatively large transactions that a sole lender would not otherwise be able (or willing) to undertake due to internal and regulatory restrictions. These loans are hybrid instruments bringing together features of relationship and transaction lending (Dennis and Mullineaux (2000)). They allow the sharing of credit risk among financial institutions without the disclosure and marketing burden that bond issuers face.

We obtain data on syndicated loans from DealScan. This database provides detailed in- 
formation on the characteristics of the loan (amount, maturity, collateral, borrowing spread, performance pricing, etc.), as well as more limited information about the members of the syndicate, the lead bank, the share of each bank in the syndicate, and the borrower. ${ }^{11} \mathrm{We}$ categorize loans as a credit line, term A, B, C, D, and E, and we exclude term loans B because banks hold none of these loans after the syndication. Term loans B are structured specifically for institutional investors and almost entirely sold off in the secondary market. Also, following Roberts (2015), we drop loans that are more likely to be amendments to existing loans; these are misreported in DealScan as new loans, but they do not necessarily involve new money.

To obtain bank financial statements, we match these data with the Call Reports. We hand-match DealScan's lender ID with the commercial bank ID (RSSD9001) from the Call Reports. This process yields a unique identity for each lender. In turn, we link the lenders at their top holding-company level (RSSD9348) to avoid losing observations. Because these reports are available on a quarterly basis, we match the origination date of the loan with the relevant quarter. For example, we match all syndicated loans originated from April 1 to June 30 with the second quarter of that year of the Call Reports. Similarly, we obtain annual information for the financial statements of firms from Compustat using the link in Chava and Roberts (2008).

The BoardEx database contains data on college education, graduate education, past employment history, current employment status, and social activities. In this study we are interested in gender information. To this end, we utilize two widely used measures:

\footnotetext{
${ }^{11}$ We apply two selection rules to avoid bias in our sample. This is an essential part of the sample-selection process that is absent from most empirical studies using the DealScan database (for a similar strategy see Lim, Minton and Weisbach (2014)). First, we disentangle banks from non-banks. We consider a loan facility to have a non-bank institutional investor if at least one institutional investor that is neither a commercial nor an investment bank is involved in the lending syndicate. Non-bank institutions include hedge funds, private equity funds, mutual funds, pension funds and endowments, insurance companies, and finance companies. To identify commercial bank lenders, we start from lenders whose type in DealScan is U.S. Bank, African Bank, Asian-Pacific Bank, Foreign Bank, Eastern Europe/Russian Bank, Middle Eastern Bank, Western European Bank, or Thrift/SELL. We manually exclude observations classified as a bank by DealScan but actually are not, such as the General Motors Acceptance Corporation (GMAC) Commercial Finance. We review all syndicated loans manually, one-by-one. Second, we exclude loans to utilities or financial companies.
} 
the absolute number of females, and the proportion of females. We then apply these two measures in four different categories. We examine: (i) the total number of female directors (\#female on BD) and the fraction of the total females on a board (\% female on BD), (ii) the number of female executive (internal) directors (\#ED female on BD) and the fraction of female executive (internal) directors (\% ED female on $B D)$, (iii) the number of female non-executive (external) directors (\# SD female on $B D$ ) and the fraction of female non-executive (external) directors (\%ED female on $B D)$, (iv) the number of female independent non-executive directors (\# indep. NED female on BD) and the fraction of female independent non-executive directors (\% indep. NED female on BD).

Due to the fact that BoardEx provides data for each director and year, we collapse this information by calculating the average per firm and year. We hand-match firms in BoardEx to Compustat. Specifically, we match the firm's name in BoardEx to the name as it appears in Compustat. This proved one of the most challenging and time-consuming tasks of the entire sample construction. In addition, we had to clean the initial data received by BoardEx. Each time a company acquires another company, BoardEx stops using the initial company ID and supplies a new one after the acquisition. This leads us to the same company name with different ID numbers for before and after the acquisition. We apply a fuzzy merge and hand-match one by one the same company before and after the acquisition by keeping the initial BoardEx company ID.

Following normal selection criteria in the literature, we control for the potential influence of outliers by excluding observations in the $1 \%$ from upper and lower tails of the distribution of the regression variables. The matching process yields a maximum of 13,714 loans from 386 banks involving 2,432 non-financial firms from 1999 to 2013. This sample is a so-called multi-level data set, which has observations on banks and firms (lower level) and loan deals (higher level). 


\subsection{Sample analysis}

In table 1 we formally define all variables in the empirical analysis and provide the data sources. In table 2 we present information about the variables used in the empirical models. More precisely, in panel A we provide the descriptive statistics for the dependent and independent variables we utilize in this study. We find that firms have on average 10 directors (executive and non executive). Of those firms, we observe on average 1.2 female directors on the board, which translates to an average of $11.3 \%$ female board representation. These statistics are in line with other studies (e.g., Sila, Gonzalez and Hagendorff (2016), Gul, Srinidhi and Ng (2011), Liu, Wei and Xie (2014), Chen, Leung and Goergen (2016), Conyon and He (2017), Bennouri, Chtioui, Nagati and Nekhili (2018)) whose samples indicate around one female directors per board and female board participation of between $9.4 \%$ and $11 \%$. The cost of borrowing, calculated by AISD, has a mean of $145.59 \mathrm{bps}$, while the Relationship dummy informs us that $51.7 \%$ of our sample consists of firms that received loans at least once in the last five years.

Our data allows us to analyze how the cost of bank borrowing changes over time for firms in our sample, as female board representation evolves at different rates. In panel B of table 2 , we show that the cost of borrowing is much lower for firms with female representation on their boards. We observe that firms with female directors pay an average AISD of 130 basis points as opposed to 183 basis points for firms with no female directors. This difference, which is significant at a $1 \%$ level, implies that firms with women on the board command significantly lower loan spreads compared to firms that are dominated by male directors. The picture is similar for the rest of the measures of cost of borrowing in this study (i.e., AISU, Commitment fee, Letter of credit fee). In summary, our univariate analysis suggests a negative association between female participation on boards and the cost of borrowing. Unexamined is whether this relation continues to hold when employing our identification strategy and whether it is causal. Also, we document firm-level differences for boards without and with female directors. We observe that larger, listed, and better-rated firms have a higher 
female representation on boards.

The Pearson correlation matrix in table A1 shows the bivariate relationships of the main variables of this study. Importantly, we continue to observe a negative association between loan spreads and female board presence. Our statistics also suggest that the negative association between the total number or percentage of female directors and the cost of borrowing derives not from female executive directors, but rather from external non executive and independent non executive female directors.

As mentioned, regression analysis determines whether these bivariate relationships carry over to a multivariate framework, and that is where we now turn our attention. Our empirical analysis proceeds in two steps. First, we examine whether and to what extent gender diversity affects the cost of borrowing once firms build relationships with banks. Second, we consider how banks perceive firms based on a number of board and firm-specific indicators.

\section{Results}

\subsection{Baseline model}

We begin our enquiry with a basic model of loan spread determination as shown in equation (3.1). We test the main hypothesis: firms with more gender-diverse boards, as measured by the number and fraction of females on the board, are more likely to command lower spreads. Table 3 presents the results when we incorporate time-invariant fixed effects. ${ }^{12}$ In columns I and II we report the results for the number and fraction of females. The remaining columns vary in how we measure the variable. Specifically, in columns III and IV we report executive females on the board, in columns $\mathrm{V}$ and VI we show the number and percentage of non executive female directors on boards, and finally in columns VII and VIII we distinguish the number and fraction of independent non executive female directors.

\footnotetext{
${ }^{12}$ In table A2 in the appendix, we repeat the baseine specifications adding sequentially fixed effects. The findings support H1a.
} 
The results show that the coefficients for female board representation are negative and highly significant in specifications I and II. That is, more gender-diverse boards, measured by the number and percentage of females on the board, have lower cost of bank lending, which is in line with H1a. This finding is statistically significant but also economically meaningful. Taking the point estimate in column II, increasing the fraction of females on the board by $1 \%$ reduces the loan spread by 20.8 basis points, representing around $14 \%$ of the sample mean. Our finding highlights the role of gender board diversity in reducing information asymmetry between firms and "arms-length" lenders, and this is reflected in banks charging lower spreads to their customers with gender-diverse boards.

When we delve deeper into the definition of female board representation, we uncover significant differences. We find in columns III and IV that the impact of the number and fraction of executive female directors is quantitatively insignificant and economically unimportant. This result echoes Liu, Wei and Xie (2014), who document that independent female directors have no effect on firm performance. We further find in the remaining specifications that the effect of female directors on loan spreads is driven primarily by non executive (external) females on the board and by independent non executive female directors. This result complements Chen, Leung and Goergen (2016), who show that dividend payout increases with the fraction of female directors, especially female independent directors. In addition, Anderson, Mansi and Reeb (2004) and Bhojraj and Sengupta (2003) find a negative association between the proportion of outside directors and bond borrowing costs. In our context, we show that independent directors maintain their independent status and strongly influence the cost of lending through the monitoring channel (L.Paige-Fields, Fraser and Subrahmanyam (2012) and Liu, Wei and Xie (2014)).

Judging from the signs of the estimated coefficients on the control variables, we find that an increase in Firm size, Profitability, and Tobin's Q, which are signs of strong balance sheets, reduce the cost of bank lending. In addition, listed firms attract lower spreads, which is consistent with the notion that presence in the stock market reduces information 
asymmetry and external financing costs. Similarly, the point estimates for the loan and bank control variables are in line with the literature. We find that loans with covenant intensity and higher maturity increase the cost of lending because higher covenants are usually linked with riskier borrowers and higher exposure, (Dennis and Mullineaux (2000)). We pay special attention to the variable capturing relationship lending. We find that repeated borrowing from the same lender reduces loan spreads by 4.2 basis points. This supports the Boot and Thakor (1994) model, which shows that relationships lower spreads.

Next, we present more restrictive models of the baseline specification by controlling for unobservable time-varying bank fundamentals to isolate credit supply and by accounting for industry demand. The firm and loan controls in the previous models remain unchanged. The combination of bank*time and industry (SIC3) fixed effects allows female representation to affect each bank at each point in time heterogeneously and account for any changes in loan supply while we control for time-invariant industry fixed effects. Table 4 explores the variation among firms with different levels of gender diversity while controlling for within bank-year variation. The reported results in this table stand both quantitatively and qualitatively.

The AISD considers the sum of the spread over LIBOR plus the facility fee while ignoring other fee components, such as the commitment fee and letter-of-credit fee. As Berg, Saunders and Steffen (2016) note, fees are an important component of the syndicated loan market because about $60 \%$ of syndicated loans contain at least one fee type in the DealScan database. Consider, for example, a line of credit: In the syndicated loan market, only around $60 \%$ of borrowers' credit lines are actually drawn down; the rest is often used for letters of credit or remains undrawn. Therefore, for a typical credit line loan, the total price can be higher or lower than the AISD depending on the various fees on the drawn or undrawn components. In table 5, we identify different spread and fee types that characterize the cost of borrowing to further support our baseline results. In particular, we use all-in-spread-undrawn (AISU), the fee on the unused amount of loan commitments (Commitment fee), and the fee on 
amounts drawn on letter-of-credit sub limits (Letter of credit fee). The results show a negative association between female board participation and the cost of borrowing; this supports our baseline results. ${ }^{13}$

Overall, the baseline specifications suggest that loan spreads decrease with the number and fraction of female directors. The evidence suggests that gender diversity helps to reduce the cost of lending. We point out, however, that the baseline model ignores one important characteristic of the lending process and of borrowers that are charged the relevant spreads. Specifically, the empirical model does not allow for the distinction between "relationship" and "transactional" borrowers, which is a significant factor in the relationship between firm characteristics and access to credit through bank lending. This distinction can be critically important because our explanatory variables have disproportionate effects on different types of firms classified by this criterion, as shown in table 3. In the next sub section, we interact dummies for relationship borrowers with the number and fraction of female directors to assess whether relationship lending is a dimension that financial markets consider.

\subsection{The role of relationship lending}

We now turn to our H1b, relating gender diversity to relationship finance. The results of estimating equation (3.2) are in table 6. Each column of table 6 corresponds to one of the alternative indicators that underlies the characterization of firms' gender diversity. For instance, columns I and II present the results exploring the number and percentage of female directors, while the remaining columns explore different attributes. In all models we interact the dummy variable for relationship lending with the variable capturing gender diversity to gauge the change in transactional borrowing. We find the net response under relationship lending by summing the coefficients.

According to the results reported in columns I and II, Female, measured both by the

\footnotetext{
${ }^{13}$ In appendix table A5, we report results controlling for information on collateral, refinancing, and covenant intensity. This is to ensure that our findings remain unchanged when we disentangle secure loans from unsecured loans. The results are qualitatively and quantitatively similar to table 4.
} 
number and fraction of female directors, and Relationship dummy are negative and highly significant. Increasing the fraction of females on a board by $1 \%$ reduces spreads by 46 basis points, as seen in column II. In addition, Relationship dummy has a negative and significant coefficient. Holding everything else equal, the cost of borrowing from a relationship lender is 14.2 basis points lower than borrowing from a non-relationship lender. Hence, we find evidence that establishing bank relationships reduces spreads. However, when we observe the interaction between relationship lending and female diversity, this effect is muted by 34 basis points for borrowers with bank relationships. In other words, although gender board diversity reduces the cost of lending, this effect diminishes once firms establish bank relationships and are "locked-in" with their lenders. As firms become more gender-diverse, which implies more transparency and smaller information opacity, the effect of relationship lending declines. The mechanism that underlies this findings is as follows. Female representation is crucial in screening the accuracy of financial reporting and thus reducing adverse selection issues based on hard information (accounting statements). However, in repeated interactions between banks and firms (relationship lending), the verification cost for the true quality of financial reporting is already discounted in the first loan. This finding concurs with Bharath, Dahiya, Saunders and Srinivasan (2009), who shows that more informationally opaque firms benefit less from relationship lending in terms of loan spreads. We find that this is the case for gender diversity as a device to signal more information transparency.

Next, we examine the effect of relationship lending by accounting for the characteristics of female directors. Columns III to VIII show, once again, that the effect of female directors on the cost of lending is driven primarily by female independent directors, as opposed to other categories. However, this effect is less potent for high-relationship borrowers. We document that firms' loan spreads have a significantly different response to gender diversity, when considering relationship lending, with respect to independent board characteristics. These results support H1b because the creation of more diverse boards leads to lower loan spreads. However, this is less the case for relationship borrowers. This finding is robust 
when we analyze the composition of the board.

To further corroborate our findings, we directly examine bank-dependent companies. In table 7 , we focus on how the pricing of bank loans varies with female board representation when firms rely heavily on bank financing. Specifically, following Santos and Winton (2008) we create a dummy variable, Bank dependent, which equals 1 for firm $i$ in year $t$ if firm $i$ does not have access to public debt markets (bond or equity issuance) within a five-year window prior to the current loan issuance; it equals zero otherwise. In turn, we subdivide our sample to bank-dependent and non-dependent firm and estimate equation (3.2) for the two sub-samples. The bank-dependent sample consists of 10,373 loans to 841 firms.

In the spirit of Kashyap, Stein and Wilcox (1993), bank dependency is associated with higher degrees of information asymmetry. In other words, bank-dependent firms lack transparency and availability of public information that can influence the cost of borrowing. During the most recent global financial crisis, banks incurred severe losses, which led them to change their risk appetites and resulted in increased lending costs to bank-dependent firms (Santos (2011)). In other words, the variable on bank dependency measures whether the firm has a financing source over and above bank financing. In line with our expectations, observing the marginal effects, we find that all else equal, bank-dependent firms (columns I-IV) pay higher spreads on their loans compared to firms with access to public markets (column V-VIII). Our results suggest that banks increase lending rates more for bank-dependent firms than for firms with access to public markets because they can utilize the soft informational power that they collect from repeated interactions. ${ }^{14}$

\footnotetext{
${ }^{14}$ To further check the robusness of our findings, we follow the relevant empirical literature (e.g., see Fazzari, Hubbard and Petersen (1988), Gilchrist, Yankov and Zakrajsek (2009)), and we classify firms as more or less likely to be financially constrained. To this end, we utilize the size, cash flow, and credit ratings as sorting devices. Tables A3 - A4 present these tests. The results are qualitatively similar to the ones in table 7 .
} 


\subsection{Gender diversity and loan purposes}

In table 8 , we dig deeper into the role of gender diversity in determining the cost of lending. Specifically, we introduce interaction terms between female representation (i.e., the number and fraction of female directors) and loans' purpose that characterize the ex-ante level of information asymmetries. The relationship between gender diversity and cost of lending is likely influenced by differences in lenders' ability to extract higher rates of return for different uses of proceeds. The purpose of the loan has useful information content beyond the signals about creditworthiness that are conveyed in loan origination. In table 8, following Angbazo, Mei and Saunders (1998), we create three dummy variables to reflect the designated purposes: general corporate, commercial paper backup and debt repayment. ${ }^{15}$ Loans for backup or refinancing prior debt obligations are likely associated with higher spreads compared to general corporate loans because lenders are able to charge higher rates for providing immediacy (Denis (1990)). General corporate, commercial paper backup and debt repayment loans represent on average $48 \%, 10 \%$, and $21 \%$ of the sample, respectively.

According to the results in table 8 , both female indicators are negative and highly significant, and the economic significance is quantitatively similar to those in table 6. All loan-purpose dummy variables are negative, apart from Debt repayment, and statistically significant at 1\%. The negative signs for Corporate purpose and Commercial paper backup are consistent with Denis (1990) because these loans can be viewed as a letter of credit, which provide positive signals about the borrower's prospects. On the contrary, the coefficient of Debt repayment supports the view that these loans are negative NPV investments that banks can use to extract higher yields to compensate for higher risk exposure. Most important, the coefficient of the interaction term in columns I-VI is positive and highly significant,

\footnotetext{
${ }^{15}$ Corporate Purposes: General corporate loans are a catch-all purpose loan category that can be used for various activities related to general operations, purchases, or working capital (inventory purchases). A unique characteristic of these loans is the lack of security. Commercial paper backup: A commitment to back a company's commercial paper program. It is typically a revolving credit, a 364-day facility, or a letter of credit. The commitment may be drawn down if the borrower is unable to roll-over or refinance maturing commercial paper. Debt repayment: A loan to refinance or consolidate existing debt prior to maturity.
} 
indicating that these specific loan purposes diminish the negative impact of the female variables on the cost of lending. In addition, in columns V-VI, we observe qualitatively similar results but quantitatively stronger results because loans for debt refinancing are viewed as negative NPV investments because they are usually utilized for defensive purposes in corporate control contests (Angbazo, Mei and Saunders (1998)). In summary, we find that the higher a loan's systemic risk exposure, the higher the ex-ante cost of the loan, given the same transparency in accounting practices arising from gender diversity. The coefficients of the marginal effect on the female variables provide useful insights for heterogeneous effects on gender diversity with respect to differences in the purpose of the granted loans.

\section{Robustness checks}

\subsection{Instrumental variable estimation}

Our evidence thus far suggests that gender diversity reduces the cost of lending due to better transparency, but this effect attenuates once firms establish relationships with banks. One may raise doubts about the extent to which gender diversity drives our results, as unobserved firm factors such as bank-firm board connectedness, may drive gender diversity and the loan spread simultaneously. Thus, lower spreads on loans might not be due to the incremental benefits of female representation as we argue thus far but may simply be the result of female variable proxying for the borrower's unobservable quality. To address this potential concern, we introduce an instrumental-variables (IV) methodology.

The identification of gender diversity requires an exogenous variable, which is correlated with female participation but does not directly affect loan spreads except through diversity. To this end, we use female retirements as an exogenous instrument for gender diversity that addresses endogeneity of board composition. Relying on BoardEx, we define a director departure as retirement if the director is at or beyond the company's mandatory retirement age. In our sample, there are 172 firms with director retirements. Our identification strategy 
is to compute changes in board composition that are not due to the firm's conditions. One way that retirements could correlate with the cost of lending is through common industry developments that tend to move together. We thus control for industry fixed effects in our empirical specification. The identifying assumption in our IV analysis is that after controlling for time-varying industry (demand-side) effects, time-varying bank (supply-side) effects, and loan characteristics, director retirements enter exogenously in gender diversity (Fracassi and Tate, 2012). This allows us to interpret our findings as arising from a change in gender diversity.

We conduct the IV analysis using a two-stage least squares model with Bank*Year, Industry*Year, and Bank*Industry FE, separately. In table 9, columns I-VI, we replicate the baseline specification of table 3 using our instruments. The first stage-point estimates in panel A confirm that director retirements lead to a significant increase in female participation on boards. This suggests that firms replace retired directors with female directors. In addition, the over-and-weak identification tests show no concerns regarding instrument validity. Panel B presents the second-stage estimates using the estimated value of the total number of females on the board of directors. The estimates are qualitatively and quantitatively similar to those in our baseline specification. Moreover, the statistical significance and inference on the coefficients of interest are very similar. In sum, our findings are robust to endogenous regressors.

\subsection{Effects of non pricing characteristics}

Overall, the results in the previous subsection indicate that, ceteris paribus, firms with gender-diverse boards borrow at a lower cost. In this subsection, we explore how changes in board composition affect non price terms. Facility amount, Fixed charge coverage, Financial covenants, and Performance pricing are key loan contract features. The motivation for this test is that the above indicators are better at lowering loan risk in the case of adverse developments for the borrower. We use, gender diversity as a proxy that is adverse 
to firm risk. So, we expect a positive effect on Facility amount and Performance pricing and a negative effect on higher needs for Fixed charge (source of general covenants) and Financial covenants. ${ }^{16}$ General covenants restrict a borrower's actions, such as acquisitions or debt issuance; financial covenants require maintaining minimum financial ratios or values, such as a maximum debt ratio.

In table 10, column I, the coefficient of interest is positive and statistically significant at the $1 \%$ level. Clearly, firms with more females directors borrow $\$ 2.8 \mathrm{M}$ than firms that are less diversified. Equally, this decreases the probability of having higher contract strictness such as fixed charge coverage and financial covenants (Murfin (2012)). Performance pricing is a relatively new provision in loan contracts. There are two types of performance pricing: interest decreasing and interest increasing. In our analysis, we consider interest decreasing, which is a relatively new payment modification option. ${ }^{17}$ In column IV, we observe that firms with higher female representation are $1.5 \%$ more likely to have an interest-decreasing performance-pricing provision.

\subsection{Other robustness tests}

In table 11 we conduct a number of additional robustness tests. To start with, we report the results only for the total number of female directors, but we also obtain similar results for the proportion of females. In columns I and II we conduct an equivalent analysis with the baseline (table 3), but we replace Relationshipdummy with continuous measures of relationship strength such as the total number (column I) and amount of loans (column II). This is a powerful test because we take into account the dynamic nature of relationship lending and compare relationship lending borrowers with the full spectrum of borrowers that a bank serves. We follow Bharath, Dahiya, Saunders and Srinivasan

\footnotetext{
${ }^{16}$ We choose borrower covenants such as fixed-charge coverage as controls as opposed to alternative accounting measures to most closely match the variables on which banks contract.

${ }^{17}$ Interest-decreasing performance pricing provisions automatically decrease the interest rate on the loan when the borrower's creditworthiness improves. It thereby reduces adverse-selection problems when asymmetric information between the borrower and lender results in a misclassification of credit risk.
} 
(2009), who use a similar approach, to measure the intensity of relationship lending. Let Number of $\operatorname{Loan}^{b \rightarrow f}$ in the last five years be the number of loans from bank $b$ to firm $f$ at time $t$, and let Total number of $l_{o a n}$ in the last five years be the total number of loans from bank $b$ during the same year to the total number of borrowers. For each possible bank-firm pair, we compute the normalized continuous relationship lending as follows:

$$
R E L(\text { number })_{b, f, t}=\frac{\text { Number of } \operatorname{loan}^{b \rightarrow f} \text { in the last five years }}{\text { Total number of } \operatorname{loan}^{b} \text { in the last five years }}
$$

The second continuous measure of relationship strength is $R E L(\$ M)$. For bank $b$ lending to borrower $f$ at time $t$, we calculate it as follows:

$$
\operatorname{REL}(\$ M)_{b, f, t}=\frac{\$ M \text { of } \operatorname{loan}^{b \rightarrow f} \text { in the last five years }}{\text { Total } \$ M \text { of } \operatorname{loan}^{b} \text { in the last five years }}
$$

For both variables, higher values reflect higher relationship-lending intensity.

We find that the effect of continuous relationship lending is qualitatively similar to the baseline, but the economic significance is higher ( 8 and 12 basis points in columns I and II, respectively). This is expected for the continuous measures of relationship strength because they capture the relative importance of the relationship borrower vis-a-vis other borrowers for each bank. In columns III and IV, we replicate the baseline regression by using data at the loan deal level and lead-arrangers only, respectively. The results remain qualitatively similar to those in our benchmark specification. In column V, we drop loans in which the lead arranger is one of the largest three U.S. banks (J.P. Morgan Chase, Bank of America, and Citigroup) based on the number of deals in which they participate. This analysis allows us to examine whether the efficiency of very large banks in originating large loan deals solely drives the results. In column VI we estimate the equation controlling for term loans (up until now we control for loan purpose by using purpose fixed effects). 
In column VII, we exclude loans for leveraged buyouts (LBOs) and mergers and acquisitions (M\&As) because they reduce the asymmetric information between banks and borrowers (Ivashina and Kovner (2011)). However, the results are almost identical to those in the baseline specifications. In column VIII, we control for firm credit ratings as a measure of opaqueness and examine how gender diversity affects loan spread. Finally, in column IX we exclude NBER recessions, which equal 1 if the U.S. economy is in a downturn as defined by the NBERs Business Cycle Dating Committee. Results are similar to the baseline specifications.

Finally, table 12 provides further sensitivity tests using corporate governance controls. A a firm might obtain loans with lower spreads not because of female board participation, but due to better corporate governance quality. For example, Anderson, Mansi and Reeb (2004) find that factors such as board independence, board size, and audit committee size reduce the cost of debt for a company. To reduce endogeneity concerns for omitted variable bias, we thus test the robustness of our baseline results in table 4 , utilizing various boardroom characteristics. To this end, we follow previous studies (e.g., Anderson, Mansi and Reeb (2004), Liu, Wei and Xie (2014)) and control for Board size, Board independence, Audit committee size, \# Ind. NED with audit experience, \# of board directorships, and Board age. Consistent with our previous results, we find that female directors' impact is still present and strong. More precisely, throughout all the specifications of table 12 (see columns I-VIII), our estimations show a negative and statistically significant relationship at $1 \%$ and $5 \%$ between female participation on boards and the cost of loans.

\section{Conclusion}

Empirical investigations of firm performance considers the effects of gender diversity but produce seemingly mixed results. In this paper, we examine how gender diversity affects the cost of lending, paying special attention to relationship lending and the degree to which 
some firms face credit constraints from financial markets and financial intermediaries, which are relaxed less quickly than for other types of firms.

Our results, based on matched firm-bank data in the U.S. over the period 1999-2013 suggest that the sensitivity of loan spreads to gender diversity is significantly higher for independent female directors. Therefore, gender diversity has an impact through the reduction of information asymmetry and improvement of transparency, and it could operate alongside the relationship lending channel to exert an influence over the cost of lending. However, we show that the beneficial effect of gender diversity diminishes with relationship lending. Finally, we uncover significant firm-level heterogeneity because the loan spreads of small firms and those that face high volatility in their cash flows are most affected by changes in gender diversity. Our findings are of interest to policy makers who should consider how firms take into account the response of firms to gender diversity when they contemplate policies that make external financing for companies more readily available. 


\section{References}

Adams, R. and Ferreira, D.: 2004, Diversity and incentives in teams: Evidence from corporate boards, Technical report.

Adams, R. and Ferreira, D.: 2009, Women in the boardroom and their impact on governance and performance, Journal of Financial Economics 94, 291-309.

Ahern, K. and Dittmar, A.: 2012, The changing of the boards: The impact on firm valuation of mandated female board representation, Quarterly Journal of Economics 127, 137-197.

Allen, F.: 1990, The market for information and the origin of financial intermediation, Journal of Financial Intermediation $\mathbf{1}(1), 3-30$.

Almeida, H. and Campello, M.: 2010, Financing frictions and the substitution between internal and external funds, Journal of Financial and Quantitative Analysis 45, 589-622.

Anderson, R., Mansi, S. and Reeb, D.: 2004, Board characteristics, accounting report integrity, and the cost of debt, Journal of Accounting and Economics 37, 315-342.

Angbazo, L. A., Mei, J. and Saunders, A.: 1998, Credit spreads in the market for highly leveraged transaction loans, Journal of Banking and Finance 22(10-11), 1249-1282.

Barber, B. and Odean, T.: 2001, Boys will be boys: gender, overconfidence, and common stock investment, Quarterly Journal of Economics 116, 261-292.

Bear, S., Rahman, N. and Post, C.: 2010, The impact of board diversity and gender composition on corporate social responsibility and firm reputation, Journal of Business Ethics 97, 207-221.

Bennouri, M., Chtioui, T., Nagati, H. and Nekhili, M.: 2018, Female board directorship and firm performance: what really matters?, Journal of Banking and Finance 88, 267-291.

Berg, T., Saunders, A. and Steffen, S.: 2016, The total cost of corporate borrowing in the loan market: Don't ignore the fees, The Journal of Finance 71(3), 1357-1392.

Bernanke, B. and Gertler, M.: 1995, Inside the black box: The credit channel of monetary policy transmission, Journal of Economic Perspectives 9, 27-48.

Bharath, S. T., Dahiya, S., Saunders, A. and Srinivasan, A.: 2009, Lending relationships and loan contract terms, The Review of Financial Studies 24(4), 1141-1203.

Bhojraj, S. and Sengupta, P.: 2003, Effects of corporate governance on bond ratings and yields: the role of institutional investors and outside directors, Journal of Business 76, 455-475.

Bøhren, Ø. and Staubo, S.: 2014, Does mandatory gender balance work? Changing organizational form to avoid board upheaval, Journal of Corporate Finance 28, 152-168.

Boone, C. and Hendriks, W.: 2009, Top management team diversity and firm performance: Moderators of functional-background and locus-of-control diversity, Management Science 55, 165-180.

Boot, A.: 2000, Relationship banking: what do we know?, Journal of Financial Intermediation 9, 7-25.

Boot, A. and Thakor, A.: 1994, Moral hazard and secured lending in an infinitely repeated credit market game, International Economic Review 35, 899-920.

Bougheas, S., Mizen, P. and Yalcin, C.: 2006, Access to external finance: Theory and evidence on the impact of firm-specific characteristics, Journal of Banking and Finance 30, 199-227.

Bradley, M. and Roberts, M.: 2015, The structure and pricing of corporate debt covenants, Quarterly Journal of Finance 5, 1-37.

Byrnes, J., Miller, D. and Schafer, W.: 1999, Gender differences in risk taking: A meta-analysis, Psychological Bulletin 125, 367-383.

Campello, M. and Chen, L.: 2010, Are financial constraints priced? Evidence from firm fundamentals and stock returns, Journal of Money, Credit and Banking 42, 1185-1198. 
Carey, M. and Nini, G.: 2007, Is the corporate loan market globally integrated? a pricing puzzle, The Journal of Finance 62(6), 2969-3007.

Carter, D., Simkins, B. and Simpson, W.: 2003, Corporate governance, board diversity, and firm value, Financial Review 38, 33-53.

Chava, S. and Roberts, M. R.: 2008, How does financing impact investment? the role of debt covenants, The Journal of Finance 63(5), 2085-2121.

Chen, J., Leung, W. and Goergen, M.: 2016, The impact of board gender composition on dividend payouts, Journal of Corporate Finance 43, 86-105.

Cheng, B., Ioannou, I. and Serafeim, G.: 2014, Corporate social responsibility and access to finance, Strategic Management Journal 35, 1-23.

Conyon, M. and He, L.: 2017, Firm performance and boardroom gender diversity: A quantile regression approach, Journal of Business Research 79, 198-211.

Cumming, D., Leung, T. and Rui, O.: 2015, Gender diversity and securities fraud, Academy of Management Journal 58, 1572-1593.

Delis, M. D., Kokas, S. and Ongena, S.: 2017, Bank market power and firm performance, Review of Finance 21(1), 299-326.

Denis, D. J.: 1990, Defensive changes in corporate payout policy: Share repurchases and special dividends, The Journal of Finance 45(5), 1433-1456.

Dennis, S. A. and Mullineaux, D. J.: 2000, Syndicated loans, Journal of Financial Intermediation 9(4), 404426 .

Diamond, D. W.: 1984, Financial intermediation and delegated monitoring, The Review of Economic Studies $\mathbf{5 1}(3), 393-414$.

Fazzari, S., Hubbard, G. and Petersen, B.: 1988, Financing constraints and corporate investment, Brookings Papers on Economic Activity 2, 141-195.

Francis, B., Hasan, I. and Wu, Q.: 2013, The impact of cfo gender on bank loan contracting, Journal of Accounting, Auditing and Finance 28, 53-78.

Galbreath, J.: 2018, Is board gender diversity linked to financial performance? the mediating mechanism of CSR, Business and Society 57, 863-889.

Galbreath, J. and Shum, P.: 2012, Do customer satisfaction and reputation mediate the CSRFP link? evidence from Australia, Australian Journal of Management 37, 211-229.

Gilbert, J. and Ivancevich, J.: 2000, Valuing diversity: a tale of two organizations, The Academy of Management Executive 14, 93-105.

Gilchrist, S., Yankov, V. and Zakrajsek, E.: 2009, Credit market shocks and economic fluctuations: Evidence from corporate bond and stock markets., Journal of Monetary Economics 56, 471-493.

Greenbaum, S. I., Kanatas, G. and Venezia, I.: 1989, Equilibrium loan pricing under the bank-client relationship, Journal of Banking and Finance 13(2), 221-235.

Gul, F., Srinidhi, B. and Ng, A.: 2011, Does board gender diversity improve the informativeness of stock prices?, Journal of Accounting and Economics 51, 314-338.

Güntay, L. and Hackbarth, D.: 2010, Corporate bond credit spreads and forecast dispersion, Journal of Banking and Finance 34, 2328-2345.

Hale, G. and Santos, J.: 2008, The decision to first enter the public bond market: The role of reputation, funding choices, and bank relationships, Journal of Banking and Finance 32, 1928-1940.

Hermalin, B. and Weisbach, M.: 1998, Endogenously chosen boards of directors and their monitoring of the ceo, The American Economic Review 88, 96-118. 
Hermalin, B. and Weisbach, M.: 2003, Boards of directors as an endogenously determined institution: A survey of the economic literature, Economic Policy Review 9, 7-26.

Hillman, A., Shropshire, C. and Cannella, A.: 2007, Organizational predictors of women on corporate boards, Academy of Management Journal 50, 941-952.

Hinz, R., McCarthy, D. and Turner, J.: 1997, Positioning pensions for the twenty-first century, in M. Gordon, O. Mitchell and M. Twinney (eds), Are Women Conservative Investors? Gender Differences in Participant-directed Pension Investments, University of Pennsylvania Press, Philadelphia, PA.

Ivashina, V. and Kovner, A.: 2011, The private equity advantage: Leveraged buyout firms and relationship banking, The Review of Financial Studies 24(7), 2462-2498.

Ivashina, V. and Scharfstein, D.: 2010, Bank lending during the financial crisis of 2008, Journal of Financial Economics $97(3), 319-338$.

Jiménez, G., Ongena, S., Peydró, J.-L. and Saurina, J.: 2014, Hazardous times for monetary policy: What do twenty-three million bank loans say about the effects of monetary policy on credit risk-taking?, Econometrica $\mathbf{8 2}(2), 463-505$.

Kashyap, A., Stein, J. and Wilcox, D.: 1993, Monetary policy and credit conditions: Evidence from the composition of external finance, American Economic Review 83, 78-98.

Klein, A.: 2002, Audit committee, board of director characteristics, and earnings management, Journal of ccounting and conomics 33(3), 375-400.

Lim, J., Minton, B. A. and Weisbach, M. S.: 2014, Syndicated loan spreads and the composition of the syndicate, Journal of Financial Economics 111(1), 45-69.

Liu, Y., Wei, Z. and Xie, F.: 2014, Do women directors improve firm performance in china?, Journal of Corporate Finance 28, 169-184.

L.Paige-Fields, Fraser, D. and Subrahmanyam, A.: 2012, Board quality and the cost of debt capital: The case of bank loans, Journal of Banking and Finance 36, 1536-1547.

Mannix, E. and Neale, M.: 2005, What differences make a difference?, Psychological Science in the Public Interest 6, 31-55.

Matsa, D. and Miller, A.: 2013, A female style in corporate leadership? evidence from quotas, American Economic Journal: Applied Economics 5, 136-169.

Minnick, C. and Noga, T.: 2010, Do corporate governance characteristics influence tax management?, Journal of Corporate Finance 16, 703-718.

Murfin, J.: 2012, The supply-side determinants of loan contract strictness, The Journal of Finance 67(5), 1565-1601.

Pandey, R., Biswas, P., Ali, M. and Mansi, M.: 2019, Female directors on the board and cost of debt: evidence from australia, forthcoming in Accounting and Finance.

Prez-Martn, A., Prez-Torregrosa, A. and Vaca, M.: 2018, Big data techniques to measure credit banking risk in home equity loans, Journal of Business Research 89, 448-454.

Ray, D.: 2005, Corporate boards and corporate democracy, Journal of Corporate Citizenship 20, 93-105.

Roberts, M. R.: 2015, The role of dynamic renegotiation and asymmetric information in financial contracting, Journal of Financial Economics 116(1), 61-81.

Santos, J.: 2011, Bank corporate loan pricing following the subprime crisis, Review of Financial Studies 24, 1916-1943.

Santos, J. A. and Winton, A.: 2008, Bank loans, bonds, and information monopolies across the business cycle, The Journal of Finance 63(3), 1315-1359. 
Sila, V., Gonzalez, A. and Hagendorff, J.: 2016, Women on board: Does boardroom gender diversity affect firm risk?, Journal of Corporate Finance 36, 26-53.

Simpson, W., Carter, D. and D'Souza, D.: 2010, What do we know about women on boards?, Journal of Applied Finance 20, 27-39.

Sufi, A.: 2007, Information asymmetry and financing arrangements: Evidence from syndicated loans, The Journal of Finance 62(2), 629-668.

Tanaka, T.: 2014, Gender diversity in the boards and the pricing of publicly traded corporate debt: evidence from japan, Applied Financial Economics 24, 247-258.

Terjesen, S., Sealy, R. and Singh, V.: 2009, Women directors on corporate boards: A review and research agenda, Corporate Governance: An International Review 17, 320-337.

Usman, M., Farooq, M., Zhang, J., Makki, M. and Khan, M.: 2019, Female directors and the cost of debt: does gender diversity in the boardroom matter to lenders?, Managerial Auditing Journal 34, 374-392.

Whited, T. and Wu, G.: 2006, Financial constraints risk, Review of Financial Studies 19, 531-539.

Winton, A.: 1995, Delegated monitoring and bank structure in a finite economy, Journal of Financial Intermediation 4(2), 158-187.

Wood, D.: 2010, Measuring corporate social performance: A review, International Journal of Management $12,50-84$. 


\section{Tables}

Table 1: Variable definitions and sources

\begin{tabular}{|c|c|c|}
\hline \multicolumn{3}{|c|}{ A. Dependent variables } \\
\hline AISD & $\begin{array}{l}\text { All-in-spread-drawn (bps), defined as the sum of the } \\
\text { spread over LIBOR plus the facility fee. }\end{array}$ & DealScan \\
\hline AISU & $\begin{array}{l}\text { All-in-spread-undrawn (bps), defined as the sum of the } \\
\text { facility fee and the commitment fee. }\end{array}$ & DealScan \\
\hline Commitment fee & $\begin{array}{l}\text { Commitment fee (bps) paid on the unused amount of } \\
\text { loan commitments. }\end{array}$ & DealScan \\
\hline Letter-of-credit fee & $\begin{array}{l}\text { Fee (bps) paid on drawn amounts on the letter-of- } \\
\text { credit sublimit. }\end{array}$ & DealScan \\
\hline Facility amount & $\begin{array}{l}\text { The loan (facility) amount in } \mathrm{M} \$ \text { weighted by the } \\
\text { bank's share. }\end{array}$ & DealScan \\
\hline $\begin{array}{l}\text { Fixed charge cover- } \\
\text { age }\end{array}$ & $\begin{array}{l}\text { Firm's ability to pay fixed charge obligations (ex- } \\
\text { penses) from its income before interest and taxes. }\end{array}$ & DealScan \\
\hline $\begin{array}{l}\text { Financial } \\
\text { covenants }\end{array}$ & $\begin{array}{l}\text { The total number of financial covenants in the loan } \\
\text { contract. }\end{array}$ & DealScan \\
\hline $\begin{array}{l}\text { Performance pric- } \\
\text { ing }\end{array}$ & $\begin{array}{l}\text { Dummy variable equal to } 1 \text { if the loan has performance } \\
\text { pricing provisions, } 0 \text { otherwise. }\end{array}$ & Dealscan \\
\hline \multicolumn{3}{|c|}{ B. Main Explanatory variables } \\
\hline \# female on BD & The number of total female directors on the board. & Boardex \\
\hline$\%$ female on $\mathrm{BD}$ & The fraction of the female directors on the board. & Boardex \\
\hline $\begin{array}{l}\# \text { ED female on } \\
\text { BD }\end{array}$ & $\begin{array}{l}\text { The number of executive (internal) female directors on } \\
\text { the board. }\end{array}$ & \\
\hline $\begin{array}{l}\% \text { ED female on } \\
\mathrm{BD}\end{array}$ & $\begin{array}{l}\text { The fraction of executive (internal) female directors on } \\
\text { the board. }\end{array}$ & Boardex \\
\hline \# SD female on BD & $\begin{array}{l}\text { The number of non-executive (external) female direc- } \\
\text { tors on the board. }\end{array}$ & Boardex \\
\hline$\%$ SD female on BD & $\begin{array}{l}\text { The fraction of non-executive (external) female direc- } \\
\text { tors on the board. }\end{array}$ & Boardex \\
\hline $\begin{array}{l}\text { \# indep. NED fe- } \\
\text { male on } \mathrm{BD}\end{array}$ & $\begin{array}{l}\text { The number of independent non-executive (external) } \\
\text { female directors on the board. }\end{array}$ & Boardex \\
\hline $\begin{array}{l}\% \text { indep. NED fe- } \\
\text { male on } \mathrm{BD}\end{array}$ & $\begin{array}{l}\text { The fraction of independent non-executive (external) } \\
\text { female directors on the board. }\end{array}$ & Boardex \\
\hline
\end{tabular}

Relationship dummy
Dummy equal to 1 if the bank lends to the same bor- Own calculation rower in the five years before the current loan, 0 otherwise. 


\begin{tabular}{|c|c|c|}
\hline $\begin{array}{l}\text { Relationship num- } \\
\text { ber }\end{array}$ & $\begin{array}{l}\text { The number of loans from the bank to the same bor- } \\
\text { rower in the past five years, over the total number of } \\
\text { loans from the bank to the total number of borrowers. }\end{array}$ & Own calculation \\
\hline $\begin{array}{l}\text { Relationship } \\
\text { amount }\end{array}$ & $\begin{array}{l}\text { The amount }(\$ M) \text { of loans from the bank to the same } \\
\text { borrower in the past five years, over the total amount } \\
(\$ M) \text { of loans from the bank to the total number of } \\
\text { borrowers. }\end{array}$ & Own calculation \\
\hline Covenant dummy & $\begin{array}{l}\text { Dummy equal to } 1 \text { if the loan has covenants, } 0 \text { other- } \\
\text { wise. }\end{array}$ & DealScan \\
\hline Maturity & Loan duration in months. & DealScan \\
\hline LBO and M\&A's & $\begin{array}{l}\text { Dummy equal to } 1 \text { if the loan's primary purpose is for } \\
\text { leveraged buyouts or M\&A. }\end{array}$ & DealScan \\
\hline Term loan & $\begin{array}{l}\text { Dummy equal to } 1 \text { if the loan is a term loan, } 0 \text { other- } \\
\text { wise. A loan is a term loan if a firm borrows a certain } \\
\text { amount for a certain length of time. }\end{array}$ & DealScan \\
\hline Collateral & $\begin{array}{l}\text { Dummy equal to } 1 \text { if the loan is linked with collateral, } \\
0 \text { otherwise. }\end{array}$ & DealScan \\
\hline Refinancing & $\begin{array}{l}\text { Dummy equal to } 1 \text { if the loan tracks the amended re- } \\
\text { stated agreements that replaces the previous contract, } \\
0 \text { otherwise. }\end{array}$ & \\
\hline Firm size & The natural logarithm of total assets. & Compustat \\
\hline NYSE & $\begin{array}{l}\text { Dummy equal to } 1 \text { if the firm is listed on the New York } \\
\text { Stock Exchange, } 0 \text { otherwise. }\end{array}$ & Compustat \\
\hline Profitability & The ratio of pre-tax profits to total assets. & Compustat \\
\hline Tobin's Q & The natural logarithm of market-to-book value. & Compustat \\
\hline Company rating & Company S\&P credit rating. & DealScan \\
\hline $\begin{array}{l}\text { Bank-dependent } \\
\text { firm }\end{array}$ & $\begin{array}{l}\text { Dummy equal to } 1 \text { if the the firm does not have ac- } \\
\text { cess to public debt markets (bond or equity issuance) } \\
\text { within a five-year window prior to the current loan is- } \\
\text { suance, } 0 \text { otherwise. }\end{array}$ & Own calculations \\
\hline Board size & The total number of directors on a board. & Boardex \\
\hline $\begin{array}{l}\text { Audit committee } \\
\text { size }\end{array}$ & The number of directors on the audit committee. & Boardex \\
\hline $\begin{array}{l}\text { \# Ind. NED with } \\
\text { audit experience }\end{array}$ & $\begin{array}{l}\text { The number of independent non-executive (external) } \\
\text { directors with functional audit experience on the } \\
\text { board. }\end{array}$ & Boardex \\
\hline $\begin{array}{l}\text { \# of board direc- } \\
\text { torships }\end{array}$ & $\begin{array}{l}\text { The mean number of directorships that board directors } \\
\text { hold. }\end{array}$ & Boardex \\
\hline Board age & The mean age of the directors on a board. & Boardex \\
\hline Bank size & The natural logarithm of total assets. & Call Reports \\
\hline Lead bank & $\begin{array}{l}\text { Dummy equal to } 1 \text { if the bank is a mandated arranger, } \\
\text { arranger, lead manager or agent, } 0 \text { otherwise. }\end{array}$ & DealScan \\
\hline Top 3 banks & $\begin{array}{l}\text { Dummy equal to } 1 \text { if lead arranger is one of the top } \\
3 \text { arrangers, namely Bank of America, Citigroup, or } \\
\text { JPMorgan Chase, } 0 \text { otherwise. }\end{array}$ & DealScan \\
\hline
\end{tabular}




\section{Instrumental variables}

\begin{tabular}{ll}
\hline Retired director & $\begin{array}{l}\text { We define a female director departure as retirement if a } \\
\text { female director is at or beyond the company's manda- } \\
\text { tory retirement age. }\end{array}$ \\
\hline \hline
\end{tabular}


Table 2: Summary statistics

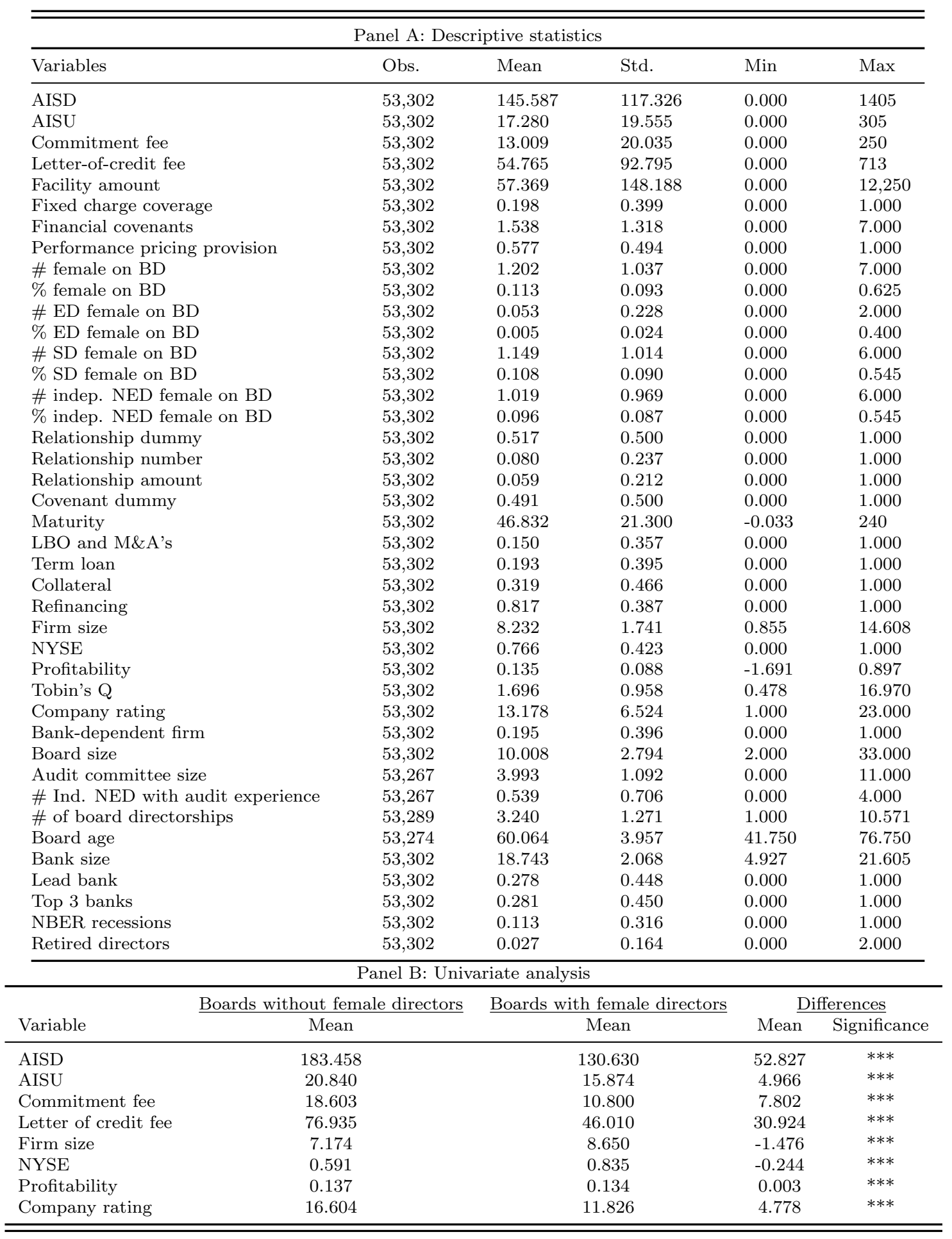

The table reports summary statistics. Panel A reports summary statistics for the variables in the empirical analysis. All variables are defined in table 1. Panel B reports differences of the various dependent variables in this study between boards without female directors and boards with female directors. The ***, **, and *, indicate significance levels at the $1 \%, 5 \%$, and $10 \%$, respectively. 


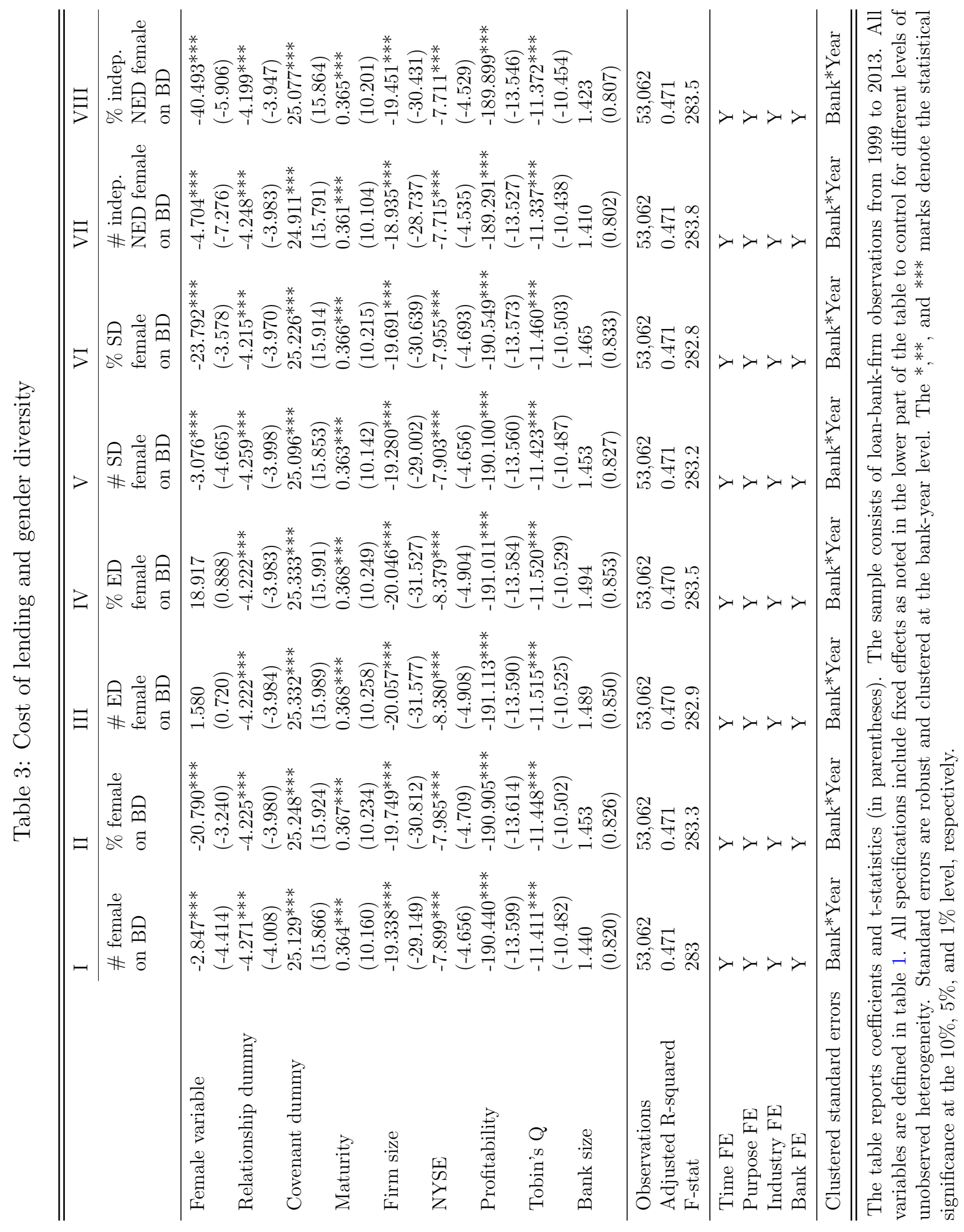




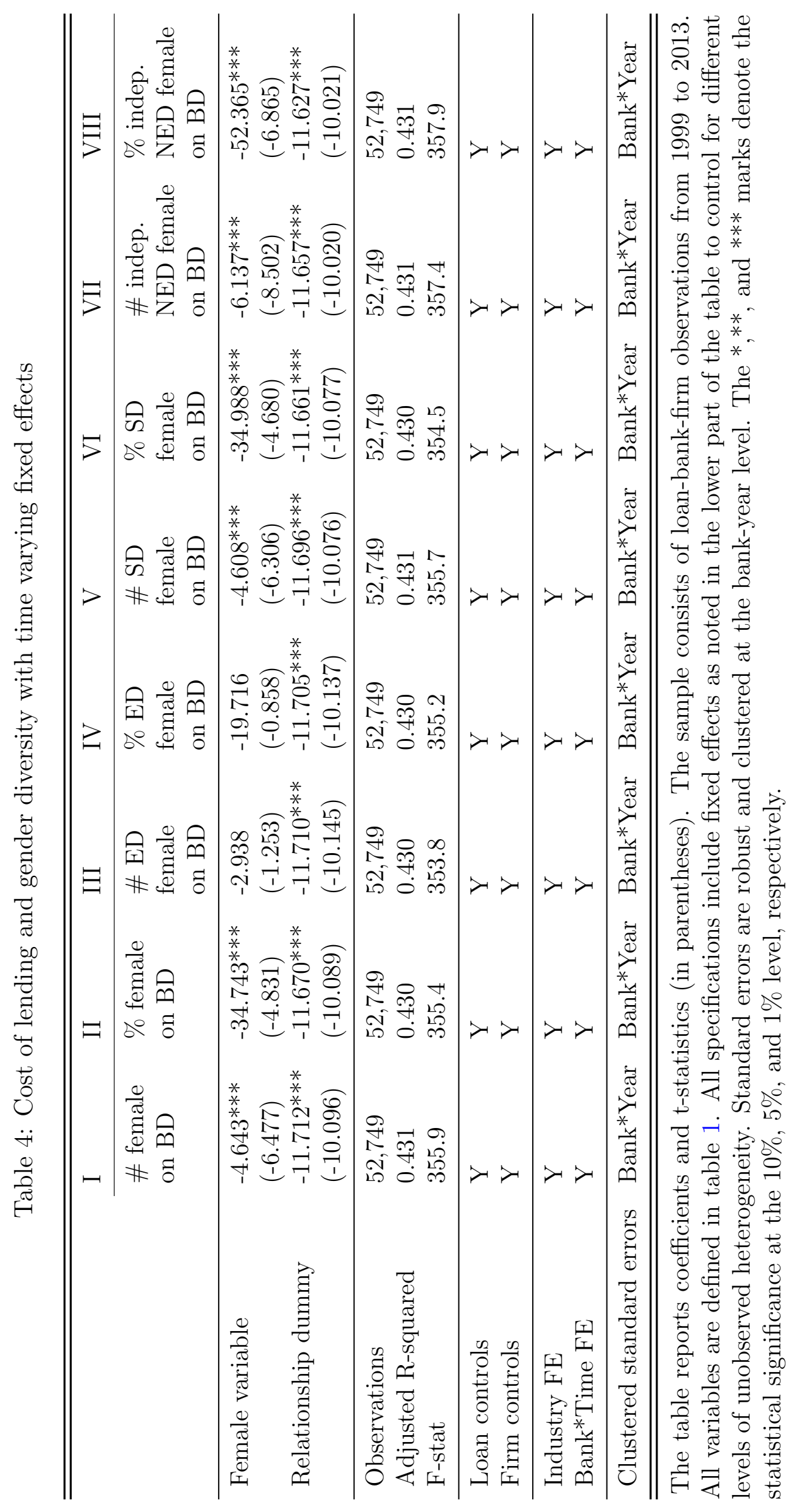




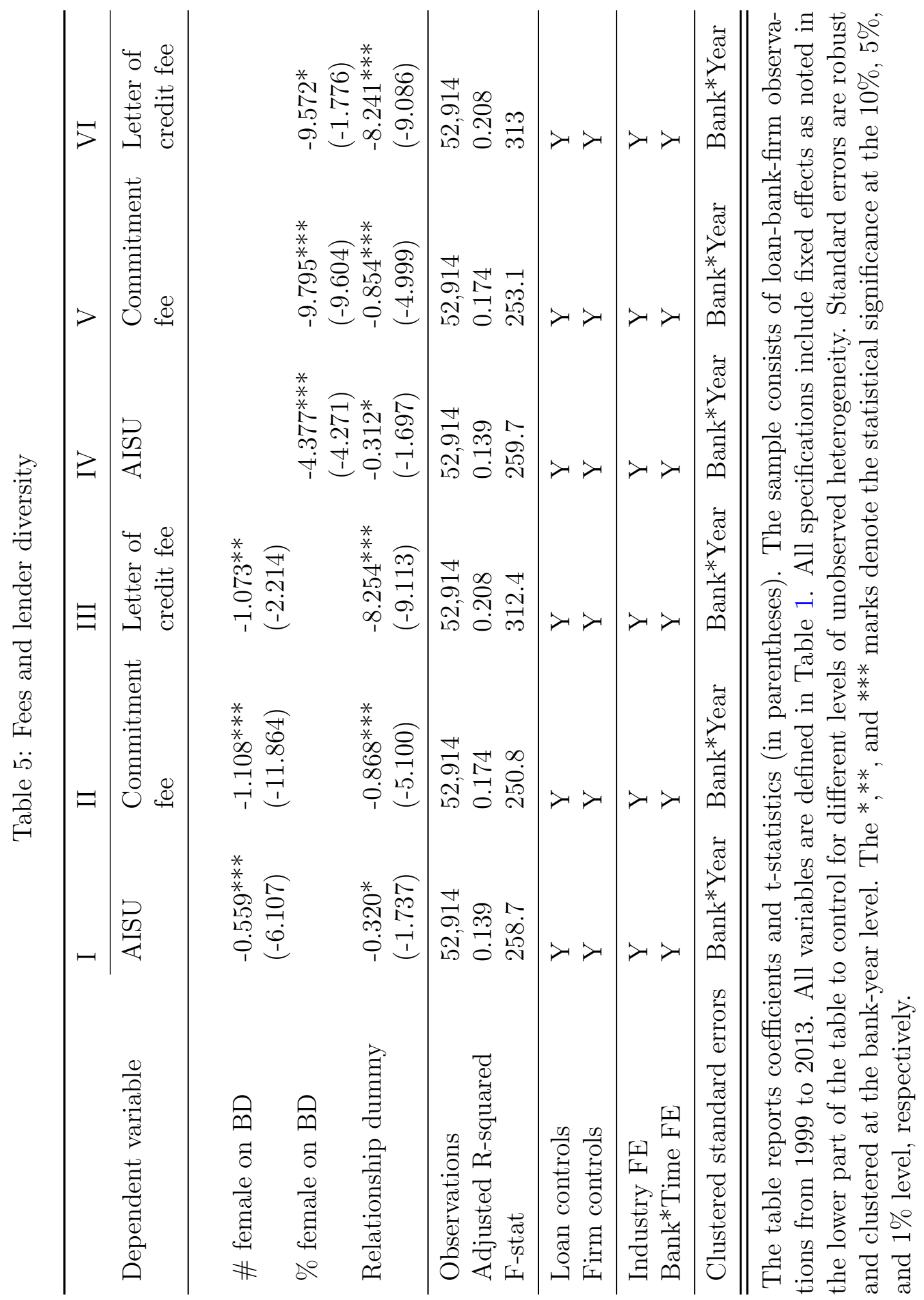




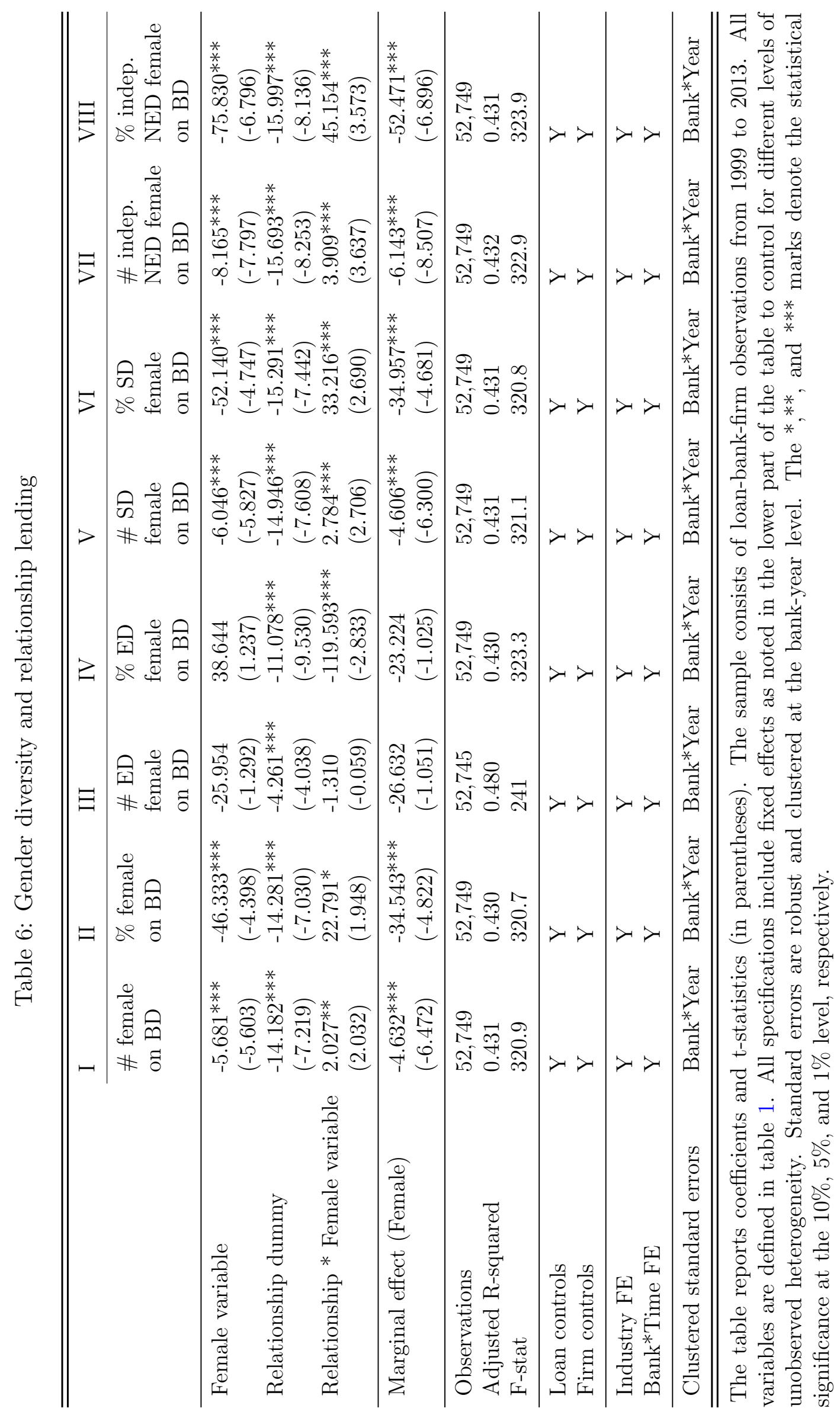




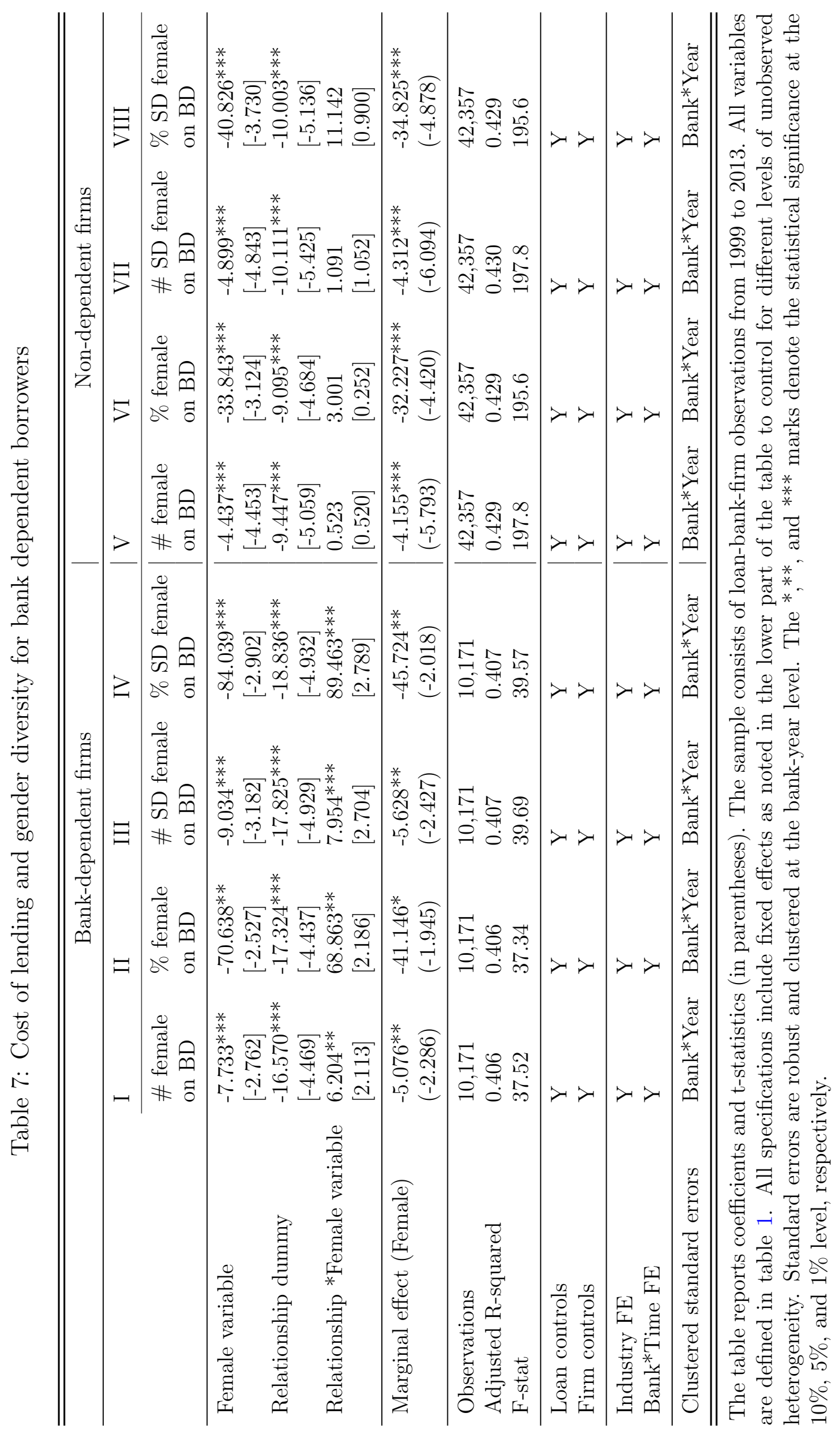


Table 8: Gender diversity and loan purpose

\begin{tabular}{|c|c|c|c|c|c|c|}
\hline & I & II & III & IV & $\mathrm{V}$ & VI \\
\hline & \multicolumn{2}{|c|}{ Corporate purpose } & \multicolumn{2}{|c|}{ Back up } & \multicolumn{2}{|c|}{ Debt repayment } \\
\hline & \#female & \%female & \#female & \%female & \#female & \%female \\
\hline Female variable & $\begin{array}{l}-6.382^{* * *} \\
(-6.990)\end{array}$ & $\begin{array}{l}-49.308^{* * *} \\
(-5.052)\end{array}$ & $\begin{array}{l}-5.393^{* * *} \\
(-7.240)\end{array}$ & $\begin{array}{l}-40.088^{* * *} \\
(-5.471)\end{array}$ & $\begin{array}{l}-4.974^{* * *} \\
(-7.104)\end{array}$ & $\begin{array}{l}-35.989^{* * *} \\
(-5.028)\end{array}$ \\
\hline Relationship dummy & $\begin{array}{l}-10.788^{* * *} \\
(-9.369)\end{array}$ & $\begin{array}{l}-11.073^{* * *} \\
(-9.649)\end{array}$ & $\begin{array}{l}-11.566^{* * *} \\
(-10.030)\end{array}$ & $\begin{array}{l}-10.787^{* * * *} \\
(-9.403)\end{array}$ & $\begin{array}{l}-11.036^{* * *} \\
(-9.646)\end{array}$ & $\begin{array}{l}-11.540^{* * *} \\
(-10.034)\end{array}$ \\
\hline Corporate purpose & $\begin{array}{l}-16.098^{* * * *} \\
(-6.882)\end{array}$ & $\begin{array}{l}-15.363^{* * *} \\
(-6.499)\end{array}$ & & & & \\
\hline Corporate purpose $*$ Female variable & $\begin{array}{l}3.782^{* * *} \\
(3.598)\end{array}$ & $\begin{array}{l}33.616^{* * *} \\
(2.793)\end{array}$ & & & & \\
\hline Commercial paper backup & & & $\begin{array}{l}-45.657^{* * *} \\
(-20.038)\end{array}$ & $\begin{array}{l}-42.417^{* * *} \\
(-17.896)\end{array}$ & & \\
\hline Commercial paper backup * Female variable & & & $\begin{array}{l}6.653^{* * *} \\
(6.518)\end{array}$ & $\begin{array}{l}56.280^{* * *} \\
(4.133)\end{array}$ & & \\
\hline Debt repayment & & & & & $\begin{array}{l}19.385^{* * *} \\
(5.710)\end{array}$ & $\begin{array}{l}23.585^{\text {*** }} \\
(6.857)\end{array}$ \\
\hline Debt repayment $*$ Female variable & & & & & $\begin{array}{l}10.591^{* * *} \\
(3.253)\end{array}$ & $\begin{array}{l}62.506^{* *} \\
(1.968)\end{array}$ \\
\hline Marginal Effect (Female) & $\begin{array}{l}-4.549^{* * *} \\
(-6.275)\end{array}$ & $\begin{array}{l}-33.017^{* * *} \\
(-4.561)\end{array}$ & $\begin{array}{l}-4.716^{* * *} \\
(-6.694)\end{array}$ & $\begin{array}{l}-34.363^{* * *} \\
(-4.905)\end{array}$ & $\begin{array}{l}-4.571^{* * *} \\
(-6.555)\end{array}$ & $\begin{array}{l}-33.609^{* * *} \\
(-4.758)\end{array}$ \\
\hline Observations & 52,749 & 52,749 & 52,749 & 52,749 & 52,749 & 52,749 \\
\hline Adjusted R-squared & 0.433 & 0.432 & 0.436 & 0.436 & 0.433 & 0.432 \\
\hline F-stat & 314.9 & 311.9 & 356.8 & 356.5 & 319.9 & 320.7 \\
\hline Loan controls & $\mathrm{Y}$ & $\mathrm{Y}$ & $\mathrm{Y}$ & $\mathrm{Y}$ & $\mathrm{Y}$ & $\mathrm{Y}$ \\
\hline Firm controls & $\mathrm{Y}$ & Y & Y & Y & $\mathrm{Y}$ & $\mathrm{Y}$ \\
\hline Industry FE & $\mathrm{Y}$ & $\mathrm{Y}$ & $\mathrm{Y}$ & $\mathrm{Y}$ & $\mathrm{Y}$ & $\mathrm{Y}$ \\
\hline Bank*Year FE & $\mathrm{Y}$ & $\mathrm{Y}$ & $\mathrm{Y}$ & $\mathrm{Y}$ & $\mathrm{Y}$ & $\mathrm{Y}$ \\
\hline Clustered standard errors & Bank*Year & Bank*Year & Bank*Year & Bank*Year & Bank*Year & Bank*Year \\
\hline
\end{tabular}

The table reports coefficients and t-statistics (in parentheses). The sample consists of loan-bank-firm observations from 1999 to 2013. All variables are defined in table 1. All specifications include fixed effects as noted in the lower part of the table to control for different levels of unobserved heterogeneity. Standard errors are robust and clustered at the bank-year level. The $*$,**, and ${ }^{* * *}$ marks denote the statistical significance at the $10 \%, 5 \%$, and $1 \%$ level, respectively. 
Table 9: Cost of lending and gender diversity: 2SLS model

\begin{tabular}{|c|c|c|c|c|c|c|}
\hline & I & II & III & IV & $\mathrm{V}$ & VI \\
\hline & \multicolumn{6}{|c|}{ Panel A: First-stage results } \\
\hline Retired director & $\begin{array}{l}0.540 * * * \\
(14.724)\end{array}$ & $\begin{array}{l}0.427^{* * * *} \\
(12.180)\end{array}$ & $\begin{array}{l}0.299 * * * \\
(8.462)\end{array}$ & $\begin{array}{l}0.046^{* * *} \\
(12.802)\end{array}$ & $\begin{array}{l}0.033^{* * *} \\
(11.296)\end{array}$ & $\begin{array}{l}0.024^{* * *} \\
(7.541)\end{array}$ \\
\hline \multirow[t]{2}{*}{ F-stat } & 633.4 & 627.5 & 449.2 & 307.7 & 358.2 & 276.5 \\
\hline & \multicolumn{6}{|c|}{ Panel B: Second-stage results } \\
\hline \# female on BD & $\begin{array}{l}-19.272^{* * *} \\
(-3.657)\end{array}$ & $\begin{array}{l}-29.329 * * * \\
(-3.339)\end{array}$ & $\begin{array}{l}-28.601^{* *} \\
(-2.556)\end{array}$ & & & \\
\hline$\%$ female on $\mathrm{BD}$ & & & & $\begin{array}{l}-225.695^{* * *} \\
(-3.564)\end{array}$ & $\begin{array}{l}-375.035^{* * *} \\
(-3.184)\end{array}$ & $\begin{array}{l}-357.610^{* *} \\
(-2.453)\end{array}$ \\
\hline Relationship dummy & $\begin{array}{l}-13.302^{* * *} \\
(-10.902)\end{array}$ & $\begin{array}{l}-11.182^{* * *} \\
(-8.089)\end{array}$ & $\begin{array}{l}-15.467^{* * *} \\
(-10.396)\end{array}$ & $\begin{array}{l}-13.110^{* * *} \\
(-10.564)\end{array}$ & $\begin{array}{l}-10.770 * * * \\
(-7.640)\end{array}$ & $\begin{array}{l}-14.976^{* * *} \\
(-9.751)\end{array}$ \\
\hline Covenant dummy & $\begin{array}{l}28.723^{* * *} \\
(16.720)\end{array}$ & $\begin{array}{l}23.967^{* * * *} \\
(11.582)\end{array}$ & $\begin{array}{l}16.624^{* * *} \\
(8.280)\end{array}$ & $\begin{array}{l}29.308^{* * *} \\
(17.066)\end{array}$ & $\begin{array}{l}24.386^{* * *} \\
(11.877)\end{array}$ & $\begin{array}{l}16.946^{* * *} \\
(8.534)\end{array}$ \\
\hline Maturity & $\begin{array}{l}0.643^{* * *} \\
(16.182)\end{array}$ & $\begin{array}{l}0.489^{* * *} \\
(10.995)\end{array}$ & $\begin{array}{l}-0.062 \\
(-1.030)\end{array}$ & $\begin{array}{l}0.658^{* * *} \\
(16.396)\end{array}$ & $\begin{array}{l}0.501^{* * *} \\
(11.402)\end{array}$ & $\begin{array}{l}-0.037 \\
(-0.644)\end{array}$ \\
\hline Firm size & $\begin{array}{l}-15.242^{* * *} \\
(-10.891)\end{array}$ & $\begin{array}{l}-14.276^{* * *} \\
(-6.133)\end{array}$ & $\begin{array}{l}-14.357^{* * *} \\
(-5.176)\end{array}$ & $\begin{array}{l}-16.810^{* * *} \\
(-15.956)\end{array}$ & $\begin{array}{l}-16.090^{* * *} \\
(-8.452)\end{array}$ & $\begin{array}{l}-16.322^{* * *} \\
(-7.598)\end{array}$ \\
\hline NYSE & $\begin{array}{l}-10.154^{* * *} \\
(-4.490)\end{array}$ & $\begin{array}{l}-9.113^{* * *} \\
(-3.600)\end{array}$ & $\begin{array}{l}-8.564^{* * *} \\
(-2.830)\end{array}$ & $\begin{array}{l}-9.177^{* * *} \\
(-3.707)\end{array}$ & $\begin{array}{l}-6.767^{* *} \\
(-2.135)\end{array}$ & $\begin{array}{l}-6.777^{*} \\
(-1.837)\end{array}$ \\
\hline Profitability & $\begin{array}{l}-134.707^{* * *} \\
(-10.252)\end{array}$ & $\begin{array}{l}-199.338^{* * *} \\
(-10.546)\end{array}$ & $\begin{array}{l}-176.640^{* * *} \\
(-10.785)\end{array}$ & $\begin{array}{l}-135.671^{* * *} \\
(-10.391)\end{array}$ & $\begin{array}{l}-202.133^{* * *} \\
(-10.702)\end{array}$ & $\begin{array}{l}-178.832^{* * *} \\
(-10.968)\end{array}$ \\
\hline Tobin's Q & $\begin{array}{l}-13.316^{* * *} \\
(-13.641)\end{array}$ & $\begin{array}{l}-9.588^{* * *} \\
(-6.754)\end{array}$ & $\begin{array}{l}-16.404^{* * *} \\
(-10.333)\end{array}$ & $\begin{array}{l}-13.083^{* * *} \\
(-13.145)\end{array}$ & $\begin{array}{l}-9.405^{* * *} \\
(-6.459)\end{array}$ & $\begin{array}{l}-16.501 \text { *** } \\
(-10.255)\end{array}$ \\
\hline Bank size & & $\begin{array}{l}0.028 \\
(0.097)\end{array}$ & $\begin{array}{l}52.155^{* * *} \\
(10.147)\end{array}$ & & $\begin{array}{l}0.139 \\
(0.465)\end{array}$ & $\begin{array}{l}54.730^{* * * *} \\
(9.641)\end{array}$ \\
\hline Observations & 52,914 & 53,008 & 51,091 & 52,914 & 53,008 & 51,091 \\
\hline Adjusted R-squared & 0.359 & 0.514 & 0.385 & 0.351 & 0.496 & 0.370 \\
\hline F-stat & 432.8 & 454.5 & 211.7 & 418.9 & 446.9 & 207.2 \\
\hline P-value for under identification & 0.000 & 0.000 & 0.000 & 0.000 & 0.000 & 0.000 \\
\hline F-stat for weak identification & 216.8 & 148.3 & 71.60 & 163.9 & 127.6 & 56.86 \\
\hline Bank*Year FE & $\mathrm{Y}$ & $\mathrm{N}$ & $\mathrm{N}$ & $\mathrm{Y}$ & $\mathrm{N}$ & $\mathrm{N}$ \\
\hline Industry*Year FE & $\mathrm{N}$ & $\mathrm{Y}$ & $\mathrm{N}$ & $\mathrm{N}$ & $\mathrm{Y}$ & $\mathrm{N}$ \\
\hline Bank*Industry FE & $\mathrm{N}$ & $\mathrm{N}$ & $\mathrm{Y}$ & $\mathrm{N}$ & $\mathrm{N}$ & $\mathrm{Y}$ \\
\hline Clustered standard errors & Bank*Year & Bank*Year & Bank*Year $^{*}$ & Bank*Year $^{*}$ & Bank*Year & Bank*Year $^{*}$ \\
\hline
\end{tabular}

The table reports coefficients and t-statistics (in parentheses). The sample consists of loan-bank-firm observations from 1999 to 2013. The first stage regressions are given in panel A and the dependent variable is \# female on BD and $\%$ female on $B D$ in columns I-III and IV-VI, respectively. Under identification: $H_{0}$ : Under-identified; Weak identification: $H_{0}$ : Weakly-identified. All variables are defined in table 1 . All specifications include fixed effects as noted in the lower part of the table to control for different levels of unobserved heterogeneity. Standard errors are robust and clustered at the bank-year level. The ${ }^{* * *}$, and ${ }^{* * *}$ marks denote the statistical significance at the $10 \%, 5 \%$, and $1 \%$ level, respectively. 
Table 10: Non pricing characteristics and gender diversity

\begin{tabular}{lllll}
\hline \hline \multirow{2}{*}{ Dependent variable } & I & II & III & IV \\
\cline { 2 - 5 } & Facility amount & $\begin{array}{l}\text { Fixed charge } \\
\text { coverage }\end{array}$ & $\begin{array}{l}\text { Financial } \\
\text { covenants }\end{array}$ & $\begin{array}{l}\text { Performance } \\
\text { pricing }\end{array}$ \\
\hline \# female on BD & $2.806^{* * *}$ & $-0.006^{* *}$ & $-0.038^{* * *}$ & $0.015^{* * *}$ \\
& $(2.733)$ & $(-2.577)$ & $(-5.385)$ & $(5.113)$ \\
Relationship dummy & $-9.125^{* * *}$ & $0.016^{* * *}$ & -0.006 & $-0.039^{* * *}$ \\
& $(-3.928)$ & $(4.036)$ & $(-0.522)$ & $(-5.504)$ \\
\hline Observations & 52,749 & 52,749 & 52,749 & 52,914 \\
Adjusted R-squared & 0.132 & 0.345 & 0.529 & 0.232 \\
F-stat & 32.02 & 277 & 574.1 & 299 \\
\hline Loan controls & $\mathrm{Y}$ & $\mathrm{Y}$ & $\mathrm{Y}$ & $\mathrm{Y}$ \\
Firm controls & $\mathrm{Y}$ & $\mathrm{Y}$ & $\mathrm{Y}$ & $\mathrm{Y}$ \\
\hline Industry FE & $\mathrm{Y}$ & $\mathrm{Y}$ & $\mathrm{Y}$ & $\mathrm{Y}$ \\
Bank*Time FE & $\mathrm{Y}$ & $\mathrm{Y}$ & $\mathrm{Y}$ & $\mathrm{Y}$ \\
\hline Clustered standard errors & Bank*Year & Bank*Year & Bank*Year & Bank*Year \\
\hline \hline
\end{tabular}

The table reports coefficients and t-statistics (in parentheses). The dependent variable is noted in the first row. The sample consists of loan-bank-firm observations from 1999 to 2013. All variables are defined in table 1. All specifications include fixed effects as noted in the lower part of the table to control for different levels of unobserved heterogeneity. Standard errors are robust and clustered at the bank-year level. The *,**, and *** marks denote the statistical significance at the $10 \%, 5 \%$, and $1 \%$ level, respectively. 


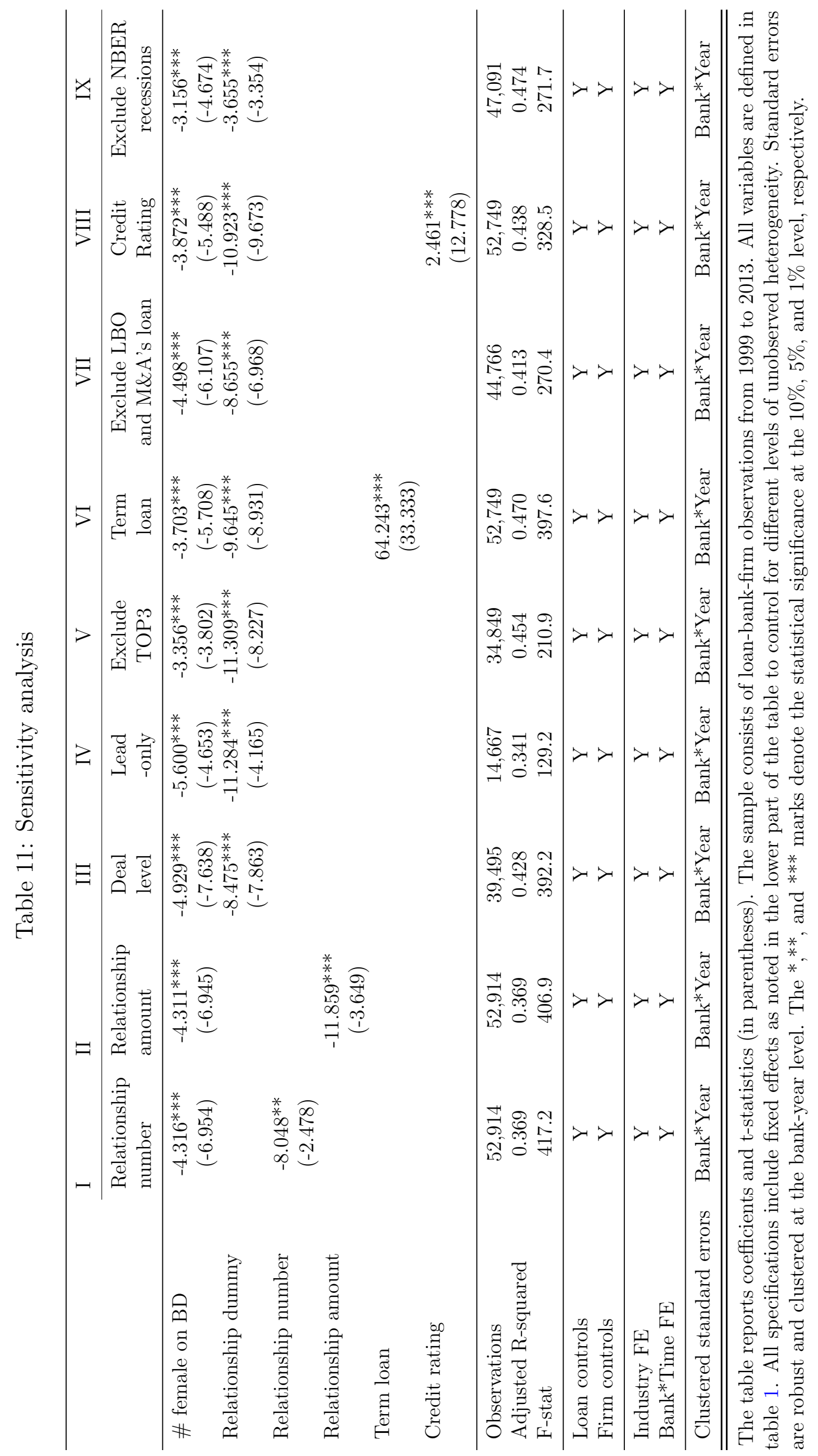




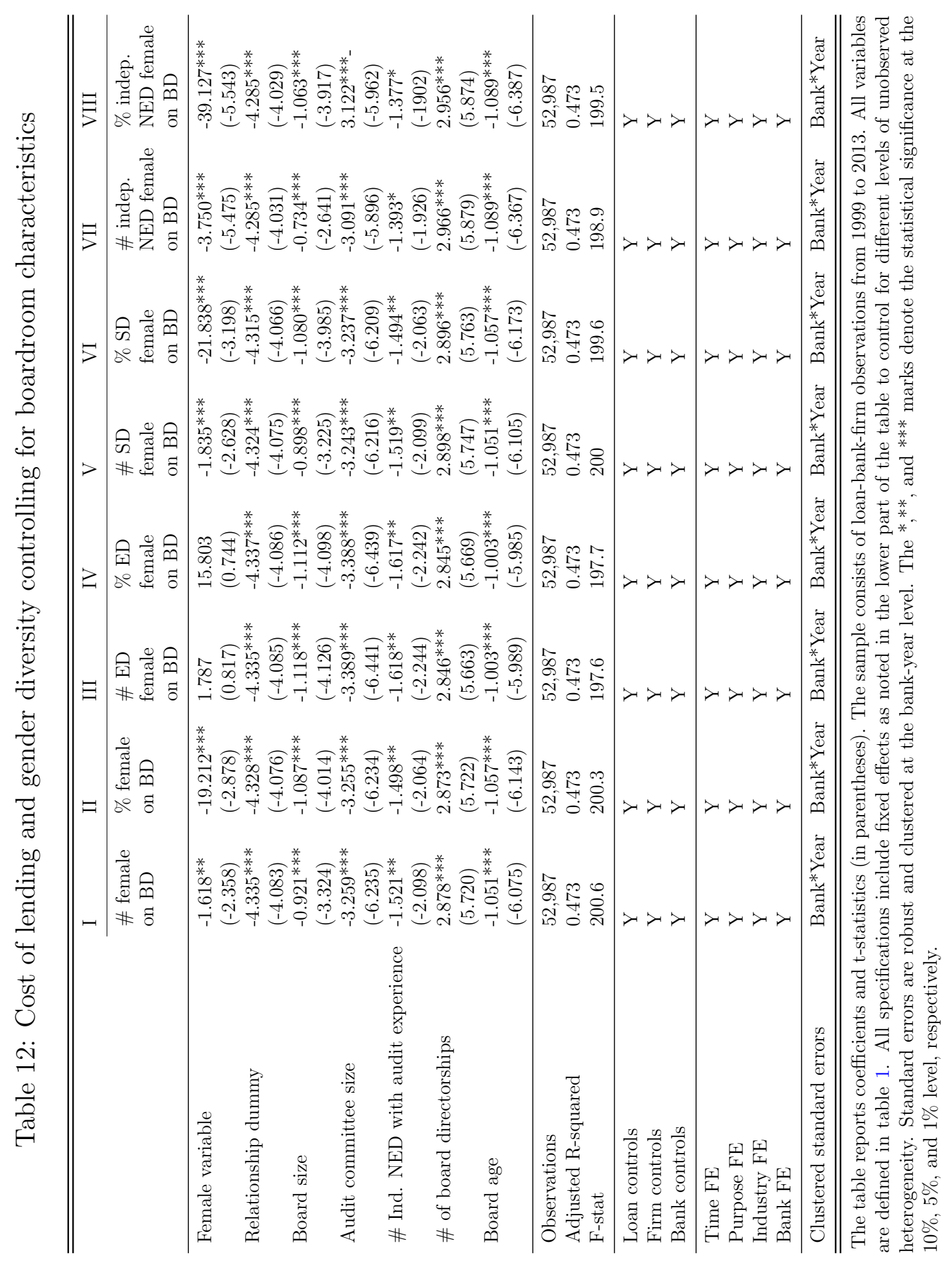


Appendix 


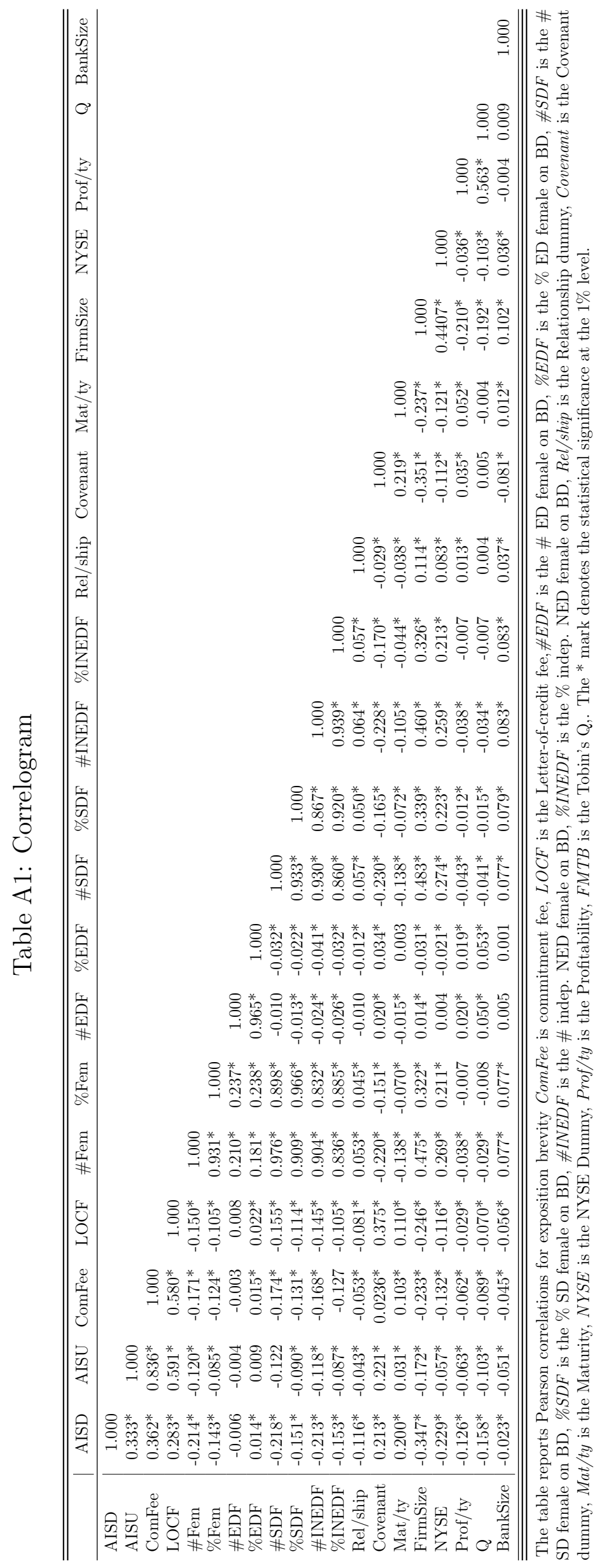


Table A2: Baseline with time-invariant fixed effects

\begin{tabular}{|c|c|c|c|c|c|c|}
\hline & I & II & III & IV & $\mathrm{V}$ & VI \\
\hline \# female on BD & $\begin{array}{l}-4.521^{* * *} \\
(-7.496)\end{array}$ & $\begin{array}{l}-3.321^{* * *} \\
(-6.042)\end{array}$ & $\begin{array}{l}-2.847^{* * *} \\
(-4.414)\end{array}$ & & & \\
\hline$\%$ female on $\mathrm{BD}$ & & & & $\begin{array}{l}-32.307^{* * *} \\
(-5.332)\end{array}$ & $\begin{array}{l}-24.259^{* * *} \\
(-4.394)\end{array}$ & $\begin{array}{l}-20.790^{* * *} \\
(-3.240)\end{array}$ \\
\hline Relationship dummy & $\begin{array}{l}-13.856^{* * *} \\
(-11.306)\end{array}$ & $\begin{array}{l}-5.853^{* * *} \\
(-5.282)\end{array}$ & $\begin{array}{l}-4.271^{* * *} \\
(-4.008)\end{array}$ & $\begin{array}{l}-13.787^{* * *} \\
(-11.269)\end{array}$ & $\begin{array}{l}-5.784^{* * *} \\
(-5.227)\end{array}$ & $\begin{array}{l}-4.225^{* * *} \\
(-3.980)\end{array}$ \\
\hline Covenant dummy & $\begin{array}{l}30.210^{* * *} \\
(17.587)\end{array}$ & $\begin{array}{l}28.120^{\text {*** }} \\
(17.999)\end{array}$ & $\begin{array}{l}25.129^{* * *} \\
(15.866)\end{array}$ & $\begin{array}{l}30.482^{* * *} \\
(17.758)\end{array}$ & $\begin{array}{l}28.300^{* * *} \\
(18.150)\end{array}$ & $\begin{array}{l}25.248^{* * *} \\
(15.924)\end{array}$ \\
\hline Maturity (months) & $\begin{array}{l}0.727^{* * *} \\
(17.497)\end{array}$ & $\begin{array}{l}0.488^{* * *} \\
(12.689)\end{array}$ & $\begin{array}{l}0.364^{* * *} \\
(10.160)\end{array}$ & $\begin{array}{l}0.733^{* * *} \\
(17.649)\end{array}$ & $\begin{array}{l}0.491^{* * *} \\
(12.773)\end{array}$ & $\begin{array}{l}0.367^{* * *} \\
(10.234)\end{array}$ \\
\hline Firm size & $\begin{array}{l}-18.926^{* * *} \\
(-31.561)\end{array}$ & $\begin{array}{l}-17.681^{* * *} \\
(-29.136)\end{array}$ & $\begin{array}{l}-19.338^{* * *} \\
(-29.149)\end{array}$ & $\begin{array}{l}-19.598^{* * * *} \\
(-34.070)\end{array}$ & $\begin{array}{l}-18.158^{* * *} \\
(-30.856)\end{array}$ & $\begin{array}{l}-19.749^{* * * *} \\
(-30.812)\end{array}$ \\
\hline NYSE dummy & $\begin{array}{l}-15.718^{* * *} \\
(-8.433)\end{array}$ & $\begin{array}{l}-12.654^{* * *} \\
(-7.597)\end{array}$ & $\begin{array}{l}-7.899^{* * *} \\
(-4.656)\end{array}$ & $\begin{array}{l}-15.924^{* * *} \\
(-8.515)\end{array}$ & $\begin{array}{l}-12.792^{* * *} \\
(-7.679)\end{array}$ & $\begin{array}{l}-7.985^{* * *} \\
(-4.709)\end{array}$ \\
\hline Profitability & $\begin{array}{l}-149.739^{* * *} \\
(-10.518)\end{array}$ & $\begin{array}{l}-150.139^{* * *} \\
(-11.304)\end{array}$ & $\begin{array}{l}-190.440^{* * *} \\
(-13.599)\end{array}$ & $\begin{array}{l}-150.551^{\text {*** }} \\
(-10.572)\end{array}$ & $\begin{array}{l}-150.673^{* * *} \\
(-11.346)\end{array}$ & $\begin{array}{l}-190.905^{* * *} \\
(-13.614)\end{array}$ \\
\hline Tobin's Q & $\begin{array}{l}-13.953^{* * *} \\
(-13.673)\end{array}$ & $\begin{array}{l}-13.466^{* * *} \\
(-13.588)\end{array}$ & $\begin{array}{l}-11.411^{* * *} \\
(-10.482)\end{array}$ & $\begin{array}{l}-14.011^{* * *} \\
(-13.716)\end{array}$ & $\begin{array}{l}-13.505^{* * *} \\
(-13.622)\end{array}$ & $\begin{array}{l}-11.448^{* * * *} \\
(-10.502)\end{array}$ \\
\hline Bank size & $\begin{array}{l}-0.282 \\
(-0.735)\end{array}$ & $\begin{array}{l}-0.054 \\
(-0.167)\end{array}$ & $\begin{array}{l}1.440 \\
(0.820)\end{array}$ & $\begin{array}{l}-0.283 \\
(-0.734)\end{array}$ & $\begin{array}{l}-0.052 \\
(-0.163)\end{array}$ & $\begin{array}{l}1.453 \\
(0.826)\end{array}$ \\
\hline Observations & 53,302 & 53,299 & 53,062 & 53,302 & 53,299 & 53,062 \\
\hline Adjusted R-squared & 0.335 & 0.397 & 0.471 & 0.334 & 0.397 & 0.471 \\
\hline F-stat & 615.7 & 420 & 283 & 599.2 & 410.3 & 283.3 \\
\hline Time FE & $\mathrm{Y}$ & $\mathrm{Y}$ & $\mathrm{Y}$ & $\mathrm{Y}$ & $\mathrm{Y}$ & $\mathrm{Y}$ \\
\hline Purpose FE & $\mathrm{N}$ & $\mathrm{Y}$ & $\mathrm{Y}$ & $\mathrm{N}$ & $\mathrm{Y}$ & $\mathrm{Y}$ \\
\hline Industry FE & $\mathrm{N}$ & $\mathrm{N}$ & $\mathrm{Y}$ & $\mathrm{N}$ & $\mathrm{N}$ & $\mathrm{Y}$ \\
\hline Bank FE & $\mathrm{N}$ & $\mathrm{N}$ & $\mathrm{Y}$ & $\mathrm{N}$ & $\mathrm{N}$ & $\mathrm{Y}$ \\
\hline Clustered standard errors & Bank*Year & Bank*Year & Bank*Year & Bank*Year & Bank*Year & Bank*Year \\
\hline
\end{tabular}

The table reports coefficients and t-statistics (in parentheses). The sample consists of loan-bank-firm observations from 1999 to 2013. All variables are defined in table 1. All specifications include fixed effects as noted in the lower part of the table to control for different levels of unobserved heterogeneity. Standard errors are robust and clustered at the bank-year level. The ${ }^{* * *}$, and *** marks denote the statistical significance at the $10 \%, 5 \%$, and $1 \%$ level, respectively. 


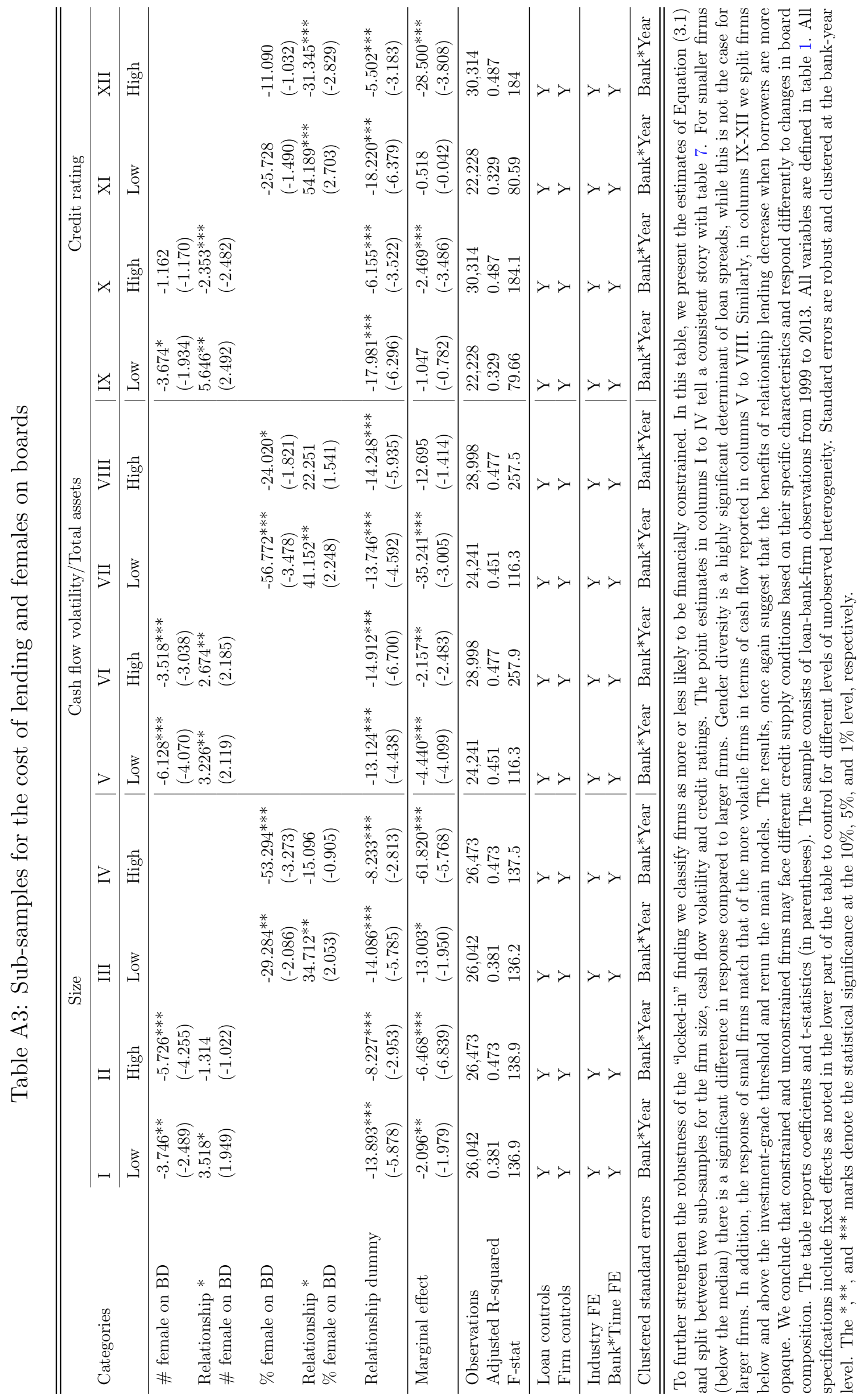




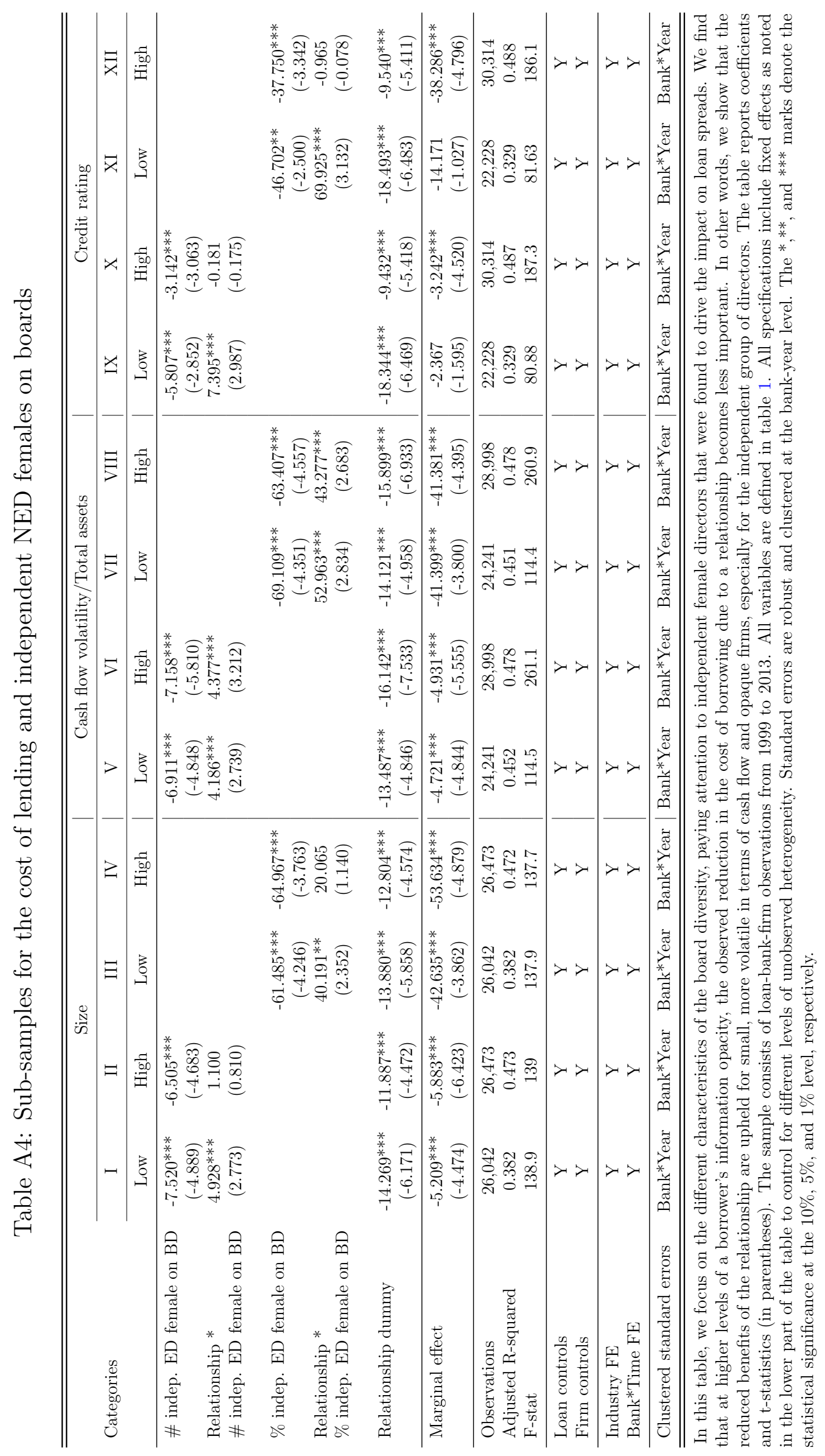


In table A5, we explore whether the existence of collateral, refinancing indicators, and financial covenant intensity can change the effect of board composition. Admittedly, one drawback of DealScan is the limited information on pledged asset. Therefore, we create a dummy variable to indicate whether the loan is linked with collateral. If a loan is secured, then the expected monetary loss for lenders should be lower and the resulting agency problems should, therefore, be less severe. In addition, DealScan has a refinancing indicator variable that tracks the amended and restated agreements that replaces the previous contract and incorporates all amendments up to the point. When firms refinance a loan, they face the risk that changes in market conditions result in refinancing at a higher interest rate. However, these loans can be viewed as renewals, which provide positive signals about a borrower's prospects. Finally, financial covenants intensity serves as a discipline device that can enhance the flexibility and efficiency of loan contraction. Higher covenants intensity assumes a higher monitoring effort to observe violations and to gather soft information. In table A5, we use the same specification with the benchmark analysis, but we add the collateral variable (columns I-II), the refinancing dummy (columns III-IV), and the financial covenant intensity (columns V-VI). The coefficient estimates of the female variable are similar in magnitude as in the baseline results and highly significant at 1\%. Also, the coefficients on the collateral variable and the refinancing dummy are both negative and statistically significant at the $1 \%$ level, while the coefficient on the financial covenant intensity is positive and highly significant at $1 \%$.

Table A5: Cost of lending and gender diversity: Secured vs. unsecured loans

\begin{tabular}{|c|c|c|c|c|c|c|}
\hline \multirow{3}{*}{ Categories } & $\mathrm{I}$ & II & III & IV & $\mathrm{V}$ & VI \\
\hline & \multicolumn{2}{|c|}{ Collateral } & \multicolumn{2}{|c|}{ Refinancing } & \multicolumn{2}{|c|}{ Financial covenants intensity } \\
\hline & \#female & $\%$ female & \#female & $\%$ female & \#female & \%female \\
\hline Female variable & $\begin{array}{l}-4.717^{* * *} \\
(-6.609)\end{array}$ & $\begin{array}{l}-35.844^{* * *} \\
(-4.997)\end{array}$ & $\begin{array}{l}-4.725^{* * *} \\
(-6.587)\end{array}$ & $\begin{array}{l}-35.382^{* * *} \\
(-4.903)\end{array}$ & $\begin{array}{l}-4.427^{* * *} \\
(-6.152)\end{array}$ & $\begin{array}{l}-32.906^{* * *} \\
(-4.570)\end{array}$ \\
\hline Collateral & $\begin{array}{l}-13.288^{* * *} \\
(-8.593)\end{array}$ & $\begin{array}{l}-13.294^{* * *} \\
(-8.589)\end{array}$ & & & & \\
\hline Refinancing dummy & & & $\begin{array}{l}-9.508 * * * \\
(-5.502)\end{array}$ & $\begin{array}{l}-9.418^{* * *} \\
(-5.444)\end{array}$ & & \\
\hline Financial covenants intensity & & & & & $\begin{array}{l}5.726^{* * *} \\
(7.365)\end{array}$ & $\begin{array}{l}5.776^{* * *} \\
(7.442)\end{array}$ \\
\hline Observations & 52,749 & 52,749 & 52,749 & 52,749 & 52,749 & 52,749 \\
\hline Adjusted R-squared & 0.433 & 0.432 & 0.432 & 0.431 & 0.433 & 0.432 \\
\hline F-stat & 314.9 & 311.9 & 356.8 & 356.5 & 319.9 & 320.7 \\
\hline Loan controls & $\mathrm{Y}$ & $\mathrm{Y}$ & $\mathrm{Y}$ & $\mathrm{Y}$ & $\mathrm{Y}$ & $\mathrm{Y}$ \\
\hline Firm controls & $\mathrm{Y}$ & $\mathrm{Y}$ & $\mathrm{Y}$ & $\mathrm{Y}$ & $\mathrm{Y}$ & $\mathrm{Y}$ \\
\hline Industry FE & $\mathrm{Y}$ & $\mathrm{Y}$ & $\mathrm{Y}$ & $\mathrm{Y}$ & $\mathrm{Y}$ & $\mathrm{Y}$ \\
\hline Bank*Year FE & $\mathrm{Y}$ & $\mathrm{Y}$ & $\mathrm{Y}$ & $\mathrm{Y}$ & $\mathrm{Y}$ & $\mathrm{Y}$ \\
\hline Clustered standard errors & Bank*Year & Bank*Year $^{*}$ & Bank*Year & Bank*Year & Bank*Year & Bank*Year \\
\hline
\end{tabular}

The table reports coefficients and t-statistics (in parentheses). The sample consists of loan-bank-firm observations from 1999 to 2013. All variables are defined in table 1. All specifications include fixed effects as noted in the lower part of the table to control for different levels of unobserved heterogeneity. Standard errors are robust and clustered at the bank-year level. The ${ }^{* * *}$, and *** marks denote the statistical significance at the 10\%, 5\%, and 1\% level, respectively. 